\title{
ALTERNATIVE TRADE STRATEGIES AND EMPLOYMENT \\ - PLAN OF RESEARCH FOR COUNTRY STUDIES
}

Anne 0. Rrueger

NBER and University of Minnesota

Work1ng Paper No. 164

(Also Issued as Project Working Paper No. I In the project on Alternative Trade Strategies and Employment)

NATIONAL BUREAC OF ECONOMIC RESEARCH, Inc. 261 Madison Avenue

New York, N.Y. 10016

January 1977

NBER working papers are distributed informally and in limited number for comments only. They should not be quoted without written permission.

This report has not undergone the review accorded officlal NBER publications; in particular, it has not yet been submitted for approval by. the Board of Directors.

The research on Alternative Trade Strategles and Employment is supported by a research contract with the U.S. Agency for International Development. 
Project Working Paper No. 1

PLAN OF RESEARCH FOR COUNTRY STUDIES

Anne 0. Krueger

Preface - - - - - - - - - - - - 1

I. Introduction $\ldots \ldots \ldots$

II. Objectives $\ldots \ldots-\ldots-\ldots$

Alternative Hypotheses - - - $-\ldots \ldots$

Current State of Knowledge on Trade Strategles - - 8

Issues with Regard to Trade Strategy and Employment - 13

The Role of Human Capital _. - . - . - 14

Other Hypotheses - - - - - . - - - 16

The Impact of Distortions - . - . - . 19

III. Basic Data Requirements for Country Studies - - - - 20

Trade Data - - - - - - - $-\ldots-\ldots$

Production and Employment Data - - . - . - 28

Employment Estimates - _ - . - . . - 29

Labor Per Unit of What? _.

Trade Regime Data - - - - - - - - - 35

Effective Protection Estimates - - - - - - - 36

Direct Price Comparisons and Tax Treatment - - 37

Computation of Factor Proportions - - - - - - 40

Preliminary Analysis of Findings - . - . . . - 45

Summary of Basic Data to be Presented - . - . - 46

IV. Analysis of the Trade Regime and Its Effects - - - 47

Effective Rates of Protect1on - - - - - - - 48

Impact of the Trade Regime on the Commodity

Composition of Trade - - . - - 50

Impact of the Trade Regime on Factor Proportions - 53

Export Promotion - - - - - - - - - 54

Import Substitution - - - - - - - - 55

v. Analysis of Factor Markets and Sk111 Requirements - - 57

Factor Market Distortions _ - _ - _ - _ - 59

Human Capital _.................. 63

(continued) 
PLAII OF RESEARCH FOR COUNTRY STUDIES

Contents (continued)

VI. The Determination of Efficient Production and Trade Patterns - 66

VII. Additional Considerations $\ldots \ldots-\ldots 1$

Primary Production - - - - - - - - - - - 72

Regional Implications - _ - _ . - . . . . 74

Multinational Corporations _ - - - - - $-\ldots$

The Impact of Uncertainty and Dynamic Comparative

Advantage - - - . - . - 77

Additional Topics _ $\ldots \ldots-\ldots$

Append1x - - - - - - - - - - - - $-\ldots$

Contents of Appendix I in Country Studies - - - - - 81

Contents of Appendix II $\ldots \ldots-\ldots 3$

Table 1. Desirable Aggregates of Employment Per Million Units 44

Sample Master Table $-\ldots-\ldots-\ldots-\ldots-\ldots-\ldots$ 


\section{PREFACE}

Th1s paper was originally prepared as part of the first stage of the research project, Alternative Trade Strategles and Employment. The project as a whole is focussed upon 1dentifying the relationships between alternative trade strategies - export promotion and import substitution - and growth in the demand for labor. The profect has altogether three stages: (1) the preparatory stage, in which the theory underlying the relationship between trade strategy and employment was developed and a methodology for undertaking empirical research was formulated; (2) the second stage, in which project participants undertook the empirical research for individual countries and also for particular topics of special interest for the project as a whole, based upon the papers prepared in the first stage; and (3) a summing up, in which the results of the individual studies are analyzed in order to ascertain what insights into the trade-employment relation seem generally applicable; At the present time, the second stage of the profect is nearlng completion.

This paper constituted one part of the first stage of the project: It spells out much of the basic methodology that underlies the Individual country studies. In early draft form, it was prepared in the summer of 1975, and all project particlpants commented upon 1t, suggesting improvements and alterations, as well as correcting errors. After the first Working Party of project participants in December 1975, at which the paper was discussed, 1t was revised, and has served as a partial basis for the methodology ised In computing employment coefficients, net factor content of trade, and related 1tems, in the ongoing research for the country studies. Not all country authors have been able to follow the procedures suggested here, due sometimes to a lack of data and in other instances to the belief that 
circumstances in their particular countries warrant alternative treatments. Nonetheless, all participants have attempted to estimate the variables discussed in this paper and, when departing from the suggested procedures, they have indicated such a departure clearly.

Because the paper in revised form has been an input into the Individual studies, it was deemed desirable to make it generally avallable In a form as close to that used in the country studies as possible. Nonetheless, in the course of the research, difficulties have arisen on a few points, and some errors have been discovered which required correction. However, the Intent in preparing this paper for the National Bureau series of Working Papers has been to keep the document as close to the revised version as is consistent with experience in using 1t. Thus, the Introduction, originally addressed to country authors, has been left unaltered, even though this Preface might better replace it were the original document not of Interest in itself. That same practice has been followed throughout, except as noted in footnotes or where ambiguous statements required clarification or errors needed correction.

The purpose of making the paper generally avallable is twofold: on the one hand, it provides some detailed materlal which will not be forthcoming elsewhere in the project and it is a part of the record of the project which should be available to interested scholars, both to enable them to have full information on the procedures used in the individual studies and also to provide detalls of the methodology which are not otherwise avallable; on the other hand, the procedures spelled out may be of Interest to researchers undertaking studies of countries not covered in the Bureau project. To the extent that the methodology devised for the project 
represents an improvement over past procedures, it is hoped that further empirical research on the trade-employment relationship will be encouraged. To the extent that chcice has to be made among alternative, equally satisfactory procedures, following the same methodology in the Bureau profect will enable comparability of results. 


\section{INTRODUCTION}

This working paper should be regarded as a companion paper to "Growth, Distortions, and Patterns of Trade Among Many Countries," which is Intended to provide a statement of much of the theory that underlies the National Bureau of Economic Research Project on Alternative Trade Strategles and Employment. It is assumed that individual researchers have already read the "Growth, Distortions, and Patterns of Trade Among Many Countries" paper. The purpose of this paper is to provide a statement, agreed to by project particlpants, as to the general way in which the Individual country studies can proceed to answer the general questions (to be discussed below) raised by the profect. In first draft form, it provided a starting point for discussion among Individual country authors and other project participants. It has been revised along lines suggested at the first Working Party of the Profect. While the content of each country study will naturally vary somewhat, based on data avallability, past research results, and conditions in the country, it is intended as an outine of the major topics, and promising ways of analyzing them, that are $11 k e l y$ to be relevant in most circumstances.

An important aspect of the philosophy underlying this profect is that each country has its own unique set of Institutions and circumstances that Influence the workings of every pollcy measure. It is for that reason that the country studies will all be undertaken by individuals who are already experts in the functioning of those economies. The suggestions made below w1ll have to be interpreted by each Individual researcher in light of the conditions in his own country. In some Instances, data avallability will determine a direction of research, or limit the extent 
one can go in a particular area. In other instances, researchers will have to use their own judgment as to the extent the lines of inquiry suggested here are pertinent, and the extent to which other avenues of analysis, less germaine to other countries, are the ones that are likely to yield the greatest insights into the questions at hand.

The working paper is organized as follows. First, Section II is devoted to setting forth the questions we hope to answer in the course of the project. In Section III, means of getting at the basic descriptive statistics needed to answer the first question - what are the current employment Implications of alternative trade strategles - are discussed. In Section IV, avenues for exploring the impact of various aspects of the trade regime on employment are set forth. In Section $V$, problems likely to be encountered in analyzing factor markets are discussed, and means of handling them are suggested. Section VI is concerned with the possibility of using programing techniques to estimate what would happen under optimal resource allocation. Section VII sets forth very brlefly some special-topics that recelve attention in other working papers.

\section{OBJECTIVES OF THE RESEARCH}

The overall research program of the NBER Project on Alternative Trade Strategies and Employment Growth is aimed at analysis and investigation of the employment Implications of export promotion and import substitution, and to ascertain the reasons for those implications. Part of our concern will be simply with the question: how much employment is generated by an additional dollar of value added in exporting compared to an additional dollar of value added in import substitution? However, that 
will only be a starting point. Major emphasis will be upon the explanation for whatever empirical findings emerge in answer to that question.

The decision to emphasize import substitution or export promotion has important ramifications upon virtually every aspect of economic activity. Those ramifications depend not only on which strategy is chosen, but also on the policy instruments used to implement the choice and on the degree of emphasis given to the chosen strategy. Thus, wild encouragement to import-substitution activities via, for example, an across-the-board 25 percent tariff may have different qualitative as well as quantitative implications for the results of an import-substitution policy than would the same strategy implemented through the prohibition of imports of any commodity once domestic production starts.

These overall ramifications of the alternative trade strategies have been extensively analyzed in a series of studies. Some of the salient results of those studies will be briefly mentioned below. For present purposes, what is important is to note that a significant omission in the research has been the employment effects of the alternative strategies and of ways in which they are implemented. The purpose of the present project is to analyze and investigate those effects, and not to evaluate the overall impact of export promotion or import substitution. It is perfectly possible that, e.g., export promotion might lead to a rapid rate of economic growth but a lower rate of employment growth. Such a conclusion would not necessarily imply a conflict between the goals of growth of output and employment, but would instead suggest that the one pollcy instrument trade strategy - could not simultaneously be used for the attainment of two separate targets. 
Estimation of the current employment levels assoclated with given amounts of Import substitution or export promotion activity does not explain why those levels occur. Consider, for example, the case where exports are encouraged by granting exporters favored access to Imported capital goods and credit. In such a circumstance, trade policy 1tself might well make the exporting of goods with high capital-labor ratios profitable, and it is conceivable that alternative means of fostering exports (or 1mport-substitution) might well have different employment ramifications. And that conclusion might follow even if exports were relatively more labor-using than Import substitutes: other means of encouraging exports might induce the selection of even more labor-1ntensive products or technology in export industries.

The example given in the last paragraph relates to the possibility that varlous policies used in Implementing the trade strategy might affect the factor proportions observed in exporting and import-substitution Industries. It is also possible, however, that other government policies (or autonomous factors), not necessarily related to the chosen trade strategy, could influence the employment coefficlents of different activities. ${ }^{1}$ If, for example, minimum wage legislation is enforced and sets the real wage rate sufficlently high so that extremely labor-using Industries cannot compete on international markets, it is possible that exports will be relatively capital-1ntensive, and of course all industries w11l use more capital-using technlques than they would at a lower wagerental ratio.

$1_{\text {See }}$ "Growth, Distortions, and Patterns of Trade Among Many Countries." 
The objective of the research project, therefore, is not only to ascertain what employment coefficients are associated with alternative trade strategies, but to analyze the reasons for those coefficients. And, by and large, it is the latter part of the project that will present the major challenge.

\section{Alternative Hypotheses}

There are several levels at which one can imagine effects of the trade regime upon employment and its rate of growth:

1. One strategy might result in a higher rate of growth of the overall economy due to superior resource allocation, and faster growth would presumably entall more employment growth.

2. Different trade strategies imply different compositions of output at each point in time. Under an export-promotion strategy, export Industries grow faster, and vice versa under import substitution. If employment per unit of output is greater in one set of Industries than in the other, then employment growth would be faster, on this account, under the strategy that lets the labor-intensive industries grow relatively faster.

3. Alternative trade policies could influence the choice of technique and capital-labor ratio in all industries, as, for example, through implicit subsidization of capital goods imports. If such policies lead to greater capital intensity and fewer jobs per unit of output in all lines of economic activity, then employment opportunities w1ll grow more slowly as there is continued capital deepening. 
It is apparent that not all three classes of effects need to be in the same direction. It is possible, in particular, that the first effect a higher rate of growth of employment due to faster output growth assoclated with export promotion - might go in one direction, while the second effect could go in the other. However, the first issue must of necessity remain outside the scope of the present study, as to Investigate it would require the rehashing of all the issues involved in the analysis of the merits of export promotion versus import substitution.

The objective of the present research profect is to come to grips with the second and third possibilities. Three alternative, mutually inconsistent, hypotheses are all possible given existing knowledge:

1. The amount of employment generated is relatively Independent of the trade strategy.

2. Import substitution generates significantly less employment growth than does an export-promotion strategy.

3. An export-promotion strategy is unlikely to entail significantly more employment growth than an import-substitution strategy and may in fact conflict with efforts to expand employment. The first possibility - that trade strategy does not affect employment very much - might be true in several ways. First, one might be able to establish the direction of difference in labor-intensity of production, but find that the difference, if any, was sufficlently small that, within the concelvable range of relative growth rates, the effects on employment would be second-order small. Second, one might find that a particular policy (such as subsidization of capital-goods imports) not really essential to the trade strategy adopted had adverse effects on employment 
and that a different set of policies could achieve the same trade strategy without the adverse employment effects. Finally, it might be that the Influences determining the composition of exporting and import-substitute Industries are independent of factor intensities, and that different relative rates of growth of the two groups of industries would not necessarily affect the rate of growth of employment.

The second possibility - that import-substitution industries require considerably less labor per unit of capital and per unit of output - is the forecast that would arise from straightforward interpretation of the two-factor Heckscher-Ohlin model of trade. Developing countries would presumably have their comparative advantage, at least in the early stages of growth, in exporting labor-intensive commodities and importing goods with relatively higher capital (and perhaps skilled labor) requirements. If that is so, it is important to know it and also the magnitude of the potential for employment creation through an export-promotion strategy. Finally, there are those who argue that export promotion and employment growth may be conflicting objectives. There are several possible reasons given. One view is that developed countries themselves have erected, or would do so if export-promotion strategies were seriously adopted, sufficiently high barriers to imports of labor-intensive goods that the developing countries can only compete in capital-intensive exports. Another basis for the argument has been the casual empiricism suggesting that the exports of some developing countries - notably Colombia and Brazil - are capital-intensive. Yet others have claimed that most of the exports of manufactured goods originating in developing countries are 
produced by branches and subsidiaries of multinational corporations which, it is alleged, use capital-intensive technology of the home country.

If, indeed, export-promoting growth is capital-intensive, there remains a question as to why it is so: the answer might lie partly in the mix of export incentives granted in the developing country and in domestic policies affecting the relative profitability of different industries. If Instead developing countries' potential manufactured exports are capitalintensive not because of distortions but because of factors associated with comparative advantage, it is important to ascertain it and to obtain some Idea of the empirical magnitude and importance of the phenomenon.

\section{Current State of Knowledge on Trade Strategies}

The basic theory of resource allocation under competition and of comparative advantage has long since provided the theoretical rationale for advocacy of relatively free trade with balanced incentives for export promotion and import substitution so that the marginal cost of earning and saving foreign exchange can be equalized. 1

Early advocates of import substitution based their case on some form of pessimism about the prospects for growth of export earnings, a secular tendency for the terms of trade for primary commodities to decline, and the need for "Industrialization." 2 Under the influence of these arguments and

${ }^{1}$ See Jagdish Bhagwati, The Theory and Practice of Commercial Policy: Departures from Unified Exchange Rates, International Finance Section, Princeton University, Special Papers in International Economics No. 8, January 1968.

${ }^{2}$ Raoul Prebisch, "Commercial Policy in the Developing Countries," American Economic Review Papers and Proceedings, May 1959. 
forelgn-exchange crises induced by excessively ambitious development and other governmental expenditures and/or the end of the Korean War boom and the consequent drop in export earnings, most developing countries adopted Import substitution as a development strategy.

The practical shortcomings of such a strategy have become painfully evident to virtually all observers, and have been extensively analyzed in research undertaken at W11liams College on import substitution and by the National Bureau of Economic Research on Forelgn Trade Reglmes and Economic Development. ${ }^{1}$ Briefly, Inftial emphasis on Import substitution led to:

1. Overvaluation of the exchange rate with consequent disincentives to potential exports, failure of forelgn exchange earnings to grow, and thus an Increasingly stringent exchange-control regime.

2. A series of partial, ad hoc incentives for exports, with increasingly complex, often Internally inconsistent bureaucratic regulations, red tape, and complextities which were a consequence of recognition of the scarcity value of foreign exchange. The result was increased demands on the bureaucracy, ever greater incentives for evasion of regulations, and mutual susplcion between the business and government sectors.

3. Increasingly high-cost Industries as the "easy" Import-substitution activities were undertaken first. This led to the loss of any gains that might otherwise have been realized from efficlent size of plant, econontes of scale, and so on.

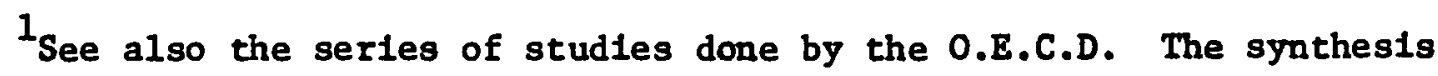
volume, which contains references to the Individual studies, is: Ian Iittle, Tibor ScItovsky, and Maurice Scott, Industry and Trade In Some Developing Countries, Oxford Press, London, 1970. 
4. Lack of competition among newly established firms. Because of the small size of market, it seldom was feasible to allow many firms in an industry, and licensing of imports of machinery precluded free entry. The result was that import-licensing mechanisms, capitalgoods licensing procedures, and other inevitable concomitants of exchange control led to the development of "lazy" entrepreneurs whose inattention to cost-consciousness, quality control, and good management was not penalized as profitability stemmed from monopoly positions and the ability to get licenses.

5. Implicit subsidization of capital goods imports. Although one might think that import-substitution policies would be across-the-board in their application, almost all countries with overvalued exchange rates were reluctant to impose surcharges and high duties on machinery and equipment imports for fear of discouraging investment. One of the effects of import-substitution policies and consequent currency overvaluation was therefore to provide implicit subsidies for imports of capital goods for such firms as were able to obtain permission to invest. 1

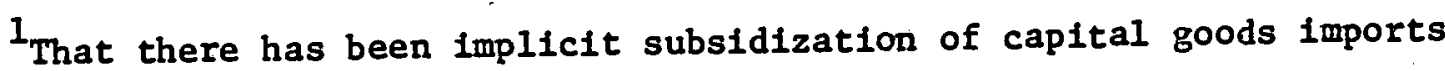
has long since been recognized. However, there have been very few attempts to quantify or estimate the importance of these subsidies and their effects on choice of techniques in developing countries. Two interesting exceptions are: James McCabe and Constantine Michalopoulos, Investment Composition and Employment in Turkey, AID Discussion Paper No. 22, October 1971, and Ibrahim Ongut, "Economic Policies, Investment Decisions, and Employment in Turkish Industry," in Duncan Miller (ed.), Labor Force and Employment in Turkey, USAID, Ankara, 1970. 
6. Increased dependence on permitted imports, largely confined to "essentlals." Whereas consumption levels were dependent on Imports at an earlier stage, import substitution led to dependence on imports of raw materials and intermediate goods for production, employment, and consumption. With "foreign exchange shortage", underutilization of capacity resulted. Economies therefore were sensitive to fluctuations in forelgn exchange earnings for production, as well as consumption, levels.

In addition, import substitution policies have often interacted with domestic economic policies in ways which theory might not have forecast. The National Bureau of Economic Research project on Forelgn Trade Regimes and Economic Development has provided documentation as to some sorts of Interaction: between Import licensing and Investment licensing; between domestic agricultural policles and the effects of the effective exchange rate in Inducing additional exports; In affecting the choice of industry, and so on. A major result of that research effort has been the demonstration of the importance of analyzing the totality of policles affecting a given 1ssue. 1

The advantages of export promotion, by contrast, appear to go somewhat beyond those suggested by the microeconomtc theory of optimal resource allocation although, of course, there can be overemphasis on export promotion as well as on Import substitution. Briefly, these additional advantages Include the following: 1) competition can be provided by the international market place and thus attention to quality control, to new techniques and

${ }^{1}$ See Jagdish Bhagwat1, Foreign Trade Regimes and Economic Development: Anatomy and Consequences of Exchange Control Regimes, NBER, forthcoming. 
products, and to good management practices is likely to be encouraged; 2) since export promotion generally entails subsidies in a variety of forms, the costs of excesses are more visible than in import substitution and there are forces within the government, especially the Ministry of Finance, which therefore places pressures against greatly imbalanced incentives; 3) efficient firms and industries can grow rapidly, without being limited to the rate of growth of domestic demand, and whatever economies of scale or Indivisibilities there are can be exhausted; and 4) governments cannot achieve their ends by reliance upon quantitative restrictions when fostering export growth, and must therefore create incentives for exporting. 1

Thus, the argument is strong that an outward-looking export-promotion strategy is more conducive to development than an import-substitution strategy. In addition, focus upon exports is likely to interact with domestic policies and variables better than import substitution, although, of course, there are better and worse ways of implementing either strategy. Moreover, there has been a significant switch in the emphasis of the developing countries over the past decade, as emphasis on import substitution has gradually lessened and encouragements for the development of exports

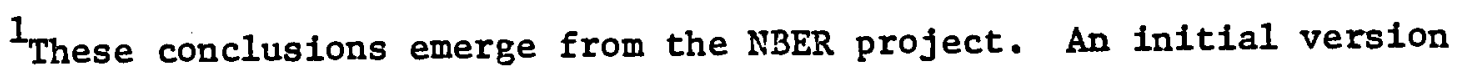
is presented in Jagdish N. Bhagwati and Anne 0. Krueger, "Exchange Control, Liberalization, and Economic Growth," American Economic Association Papers and Proceedings, May 1973. A more complete statement is contained in Anne 0. Krueger, Foreign Trade Reglmes and Economic Development: Liberalization Attempts and Consequences, $\mathrm{Ch}$. XII. 
particularly of non-traditional products, have begun. The question as to how that switch in policy will affect employment is therefore extremely Important.

\section{Issues with Regard to Trade Strategy and Employment}

In view of the above findings, it is surprising that the employment Implications of alternative trade strategles have not been carefully examined. There are several interrelated 1ssues: 1) the determinants of the commodity composition of exports under ideal resource allocation; 2) the effects of output-market Imperfections and/or incentives upon the mix of output and trade; 3) the effects of factor-market interventions upon the output mix; and 4) the effects of factor-market distortions upon the cholce of technique. The theory underlying these issues is complex, and 1s dealt with in the paper, "Growth, D1stortions, and Patterns of Trade Among Many Countries," which is a companion paper to this one.

In that paper, the hypotheses that emerge from the Heckscher-OhIIn factor proportions explanation of trade are spelled out in the context of a model wherein there is a primary-product sector using labor and natural resources, and a manufacturing sector whereln there are $n$ commodities, each employlng labor and capital in the production process. Those hypotheses can serve as a basis for the empirical work to be done in the country studies, although authors may wish to delve beyond that, especlally into issues pertaining to the determinants of factor proportions in primary commoditles and to alternative theories of the determinants of trade patterns in Individual cases.

The hypotheses that emerge from the "Growth, Distortions, and Patterns of Trade Among Many Countries" paper are several, and gathering data for 
testing them w111 constitute one of the basic tasks of the country studies. They are therefore discussed in Section III below. For present purposes, It is only necessary to note that those hypotheses pertain to the factor proportions explanation of trade for the manufacturing sector in the context of a two-factor (capital and labor) model of manufacturing. In some countries, it may prove desirable to delve extensively into factor proportions in primary comodity production, although in many cases data avallability w11l stop that line of endeavor. Insofar as data are avallable, the same basic techniques to be employed in estimating factor proportions In manufacturing w111 be usable for estimating labor coefficlents in primary commodity production. There are, to be sure, some special issues that arise In dealing with natural resources and NRB Industries, espectally agriculture. Those topics are dealt with in Section VII.

In addition, alternative explanations of the commodity composition of trade have been put forth, and country authors will undoubtedly want to explore them especially when their original tests of the Hos model prove inconclusive. It therefore seems appropriate briefly to spell out those alternative explanations, remembering that factor and good market distortions can alter observed trade flows regardless of which explanation of trade is valid, and that the analysis of Part II of the "Growth, Distortions, and Patterns of Trade Among Many Countrles" paper can therefore be applied. The Role of Human Capital. While there have been several efforts at a richer interpretation of the Heckscher-Oh11n-Samuelson model (hereafter HOS), the one of importance for present purposes relates to the incorporation of an additional factor of production into the model: human capital, or skills. Several authors have argued that recognition of the role of investment in 
human capital is the missing ingredient in interpreting the HOS model, and that incorporation of that element will yileld satisfactory Interpretation of the factor intensity of world trade flows. 1

There are two ways in which investment in humans can be regarded: 1) as one type of capital formation; or 2) as a separate factor of production. In the former interpretation, one could proceed along the Ines suggested by Kenen, arguing that employers invest in machines and in training their workers, and that both forms of investment are simply "capital." In that case, measurement only of the physical capital associated with a given activity would be in error: the relevant amount of capital per unit of output in a given activity would be the value of the services of the physical equipment used plus the value of the human capital used per unit of output. If Indeed saving can be allocated in any proportion between physical and human capital accumulation, it might be that the appropriate concept of "capital" within the HOS model would be one valuing both sorts. ${ }^{2}$ This varlant can therefore be readily tested whenever data on either the

$1_{\text {See P. B. Kenen, "Nature, Capital and Trade," Journal of Political }}$ Economy, Oct. 1965, and A. O. Krueger, "Factor Endowments and Per Capita Income Differences Among Countries," Economic Journal, September 1968. ${ }^{2}$ As there is no market in humans, the question arises as to how to value the human capital. One way is to estimate the relevant discount rate, and capttalize the difference between skilled and unskflled wages to get an estimate of the value of the stock. This method was follows by Kenen in "Nature, Capital and Trade." An alternative is to add the differential wage to the value of capital services. 
skill composition of the labor force employed in alternative activities, or the wage differential for skilled workers in each activity, can be obtained. ${ }^{1}$

If, however, human capital is a separate factor of production, a major difficulty is that few empirically testable predictions are forthcoming. Even defining the factor intensity of trade in a meaningful way is difficult, if not impossible, in a three-factor model, unless there is some hypothesis about the systematic Interrelationship between the inputs of two of the factors. If, for example, human and physical capital were separate factors but complements, while unskilled labor was a substitute for those two factors, then meaningful testing would be possible if one was prepared, also, to state that a particular country is relatively well or badly endowed with both human and physical capital. Means of examining these questions are suggested in Section III, although in many cases the degree of emphasis given to examining the role of skills and human capital will be limited by data availability and also by the presence of topics with a higher research pay-off within the time available for the study. Other Hypotheses. Although none have been formally developed as a model, there are several other hypotheses in the literature as to the determinants of the commodity composition of trade. They are noted here, mostly so that country authors can be alert for factors that should be evaluated if they are found in individual countries' circumstances.

${ }^{1}$ See Section III below for details. It should be noted that wage differentials can be used only if data are standardized with respect to large-scale and small-scale firms and other systematic sources of wage differentials. See Section $\mathrm{V}$ below. 
Most of these models, such as Linder's, ${ }^{1}$ relate the determination of a country's exports to/domestic demand patterns. As such, they imply that there will be little or no relationship between the comodity composition of trade and factor endowments, unless domestic demand patterns are somehow influenced by the country's factor endowment. It harfly seems likely that this sort of hypothesis will be relevant to the explanation of developing countries' employment coefficients in exporting and import-substitution Industries. An exception, perhaps indicative of the limited explanatory powers of the hypothesis for developing countries, would be exports of local handicrafts. Even then, handicrafts may be in demand domestically because labor is cheap, and thus there is a question as to whether domestic demand or factor proportions is the appropriate explanation.

The Vernon ${ }^{2}$ model uses the HOS model for determination of low-cost location at each point of time, but adds the notion that there are stages in a product's life, and that each stage is associated vith a particular factor-intensity of production: innovation and development (a human capital Intensive phase), shaking down (presumably capital-intensive) and standardized production (presumably labor-intensive). Each of these stages is

\section{${ }^{1}$ S. Linder, An Essay on Trade and Transformation, Wiley (New York)}

1961. See also I. Kravis, "Avallability and Other Influences on the Comodity Composition of Trade," Journal of Polltical Economy, April 1956.

W. D. Gruber, D. Mehta, and R. Vernon, "The $R$ and D Factor in International Investment of United States Industries," Journal of Political Economy, Feb. 1967, and R. Vernon, "International Investment and International Trade in the Product Cycle," Quarterly Journal of Economics, May 1966. 
Implicitly identified with a least-cost location, and thus a commodity's status as an export or Import substitute is determined by 1 ts stage relative to the country's factor endowment. In that sense, the Vernon model really puts forth one additional hypothesis: developing countries, which are presumably labor-abundant, will have a comparative advantage in producing commodities that were invented and produced elsewhere earlier on. It seems highly unlikely that any country's employment relation will be sufficiently clear-cut from Initial examination that authors will find it desirable to explore the Vernon hypothesis in depth. Nonetheless, it should be borne in mind in evaluating the empirical findings on the individual country studies. The alternative hypothesis to the Hos model that appears to be most relevant from the viewpoint of investigating the trade strategy-employment relation is the one that originates in the multinational enterprise 1iterature, namely that multinational corporations are the only organizations with capacity for rapid development of sizable manufactured exports from developing countries. 1 The argument then proceeds with the assertion that the MNC's use their parent technology in the producing country regardless of the country's factor proportions, and that $\mathrm{MMC}^{\prime} \mathrm{s}$ tend to be capital-intensive in their techniques of production. Testable hypotheses can be developed from this argument, and the data needed for such a test are discussed in Section III. At this stage, it is only necessary to note that some argue

${ }^{1}$ This hypothesis can be related to the Vernon hypothesis in that, as casual observation suggests, multinational firms are especially likely to be alert to possibilities of shifting production to new low-cost sites as comparative advantage changes over the life cycle of products. 
that multinational corporations attempt to prevent their subsidiaries from exporting. If it is belleved that those subsidiaries would otherwise export, such constraints must be regarded as a distortion, influencing the commodity composition of trade away from what it would be under an efficient allocation. of course, to the extent that multinational corporations Invest in a particular country only to take advantage of a sheltered domestic market, the real question w111 pertain to whether the industry would be part of the country ${ }^{\prime} s$ pattern of specialization in the absence of protection, an issue covered when discussing tests of the HOS hypothesis in the presence of goods market distortions in Section IV. ${ }^{1}$

The Impact of Distortions. Since much of the "Growth, Distortions, and Patterns of Trade Among Many Countrles" paper is given to an analysis of the effects of interventions and imperfectly functioning markets on observed trade patterns, 11ttle needs to be sald here. There has been a great deal of work in recent years on the issue of resource pulls resulting from various Interventions in the goods market, and the outcome has been that 1ittle can be said In theory: empirtcal work is required to resolve the issue. ${ }^{2}$ These

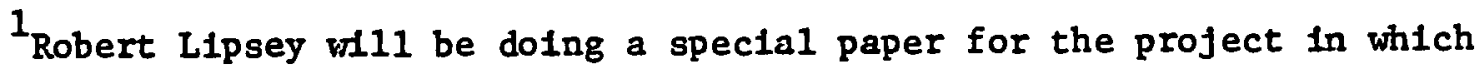
he Investigates multinationals' cholces of technique across countries. That paper, however, w111 relate to substitution possibilities, and not to the reasons why multinationals choose to Invest in particular countries. 2 See the discussions by W. Ethler and R. Ruffin In H. Grubel and B. G. Johnson (eds.), Effective Tariff Protection, GATT (Geneva), 1972; W. i1. Corden, The Theory of Protection, Oxford, 1971; J. Bhagwat1 and T. N. Srinivasan, "The General Equilibrium Theory of Effective Protection and Resource Allocation," Journal of International Economics, August 1973. 
theoretical considerations w1l make it necessary to delve into effective protective rates and related aspects of the incentive structure for import substitution and exports.

Distortions do not occur only in the goods market. Just as price changes can generate resource pulls, changes in factor prices affect the relative profitability of various activities or of alternative factor combinations in any given activity, and hence alter the pattern of output and factor use from that which would occur under optimal resource allocation. As shown in "Growth, Distortions, and Patterns of Trade Among Many Countries," in countries where there is reason to believe that significant factor market distortions exist within the manufacturing sector, considerable attention will have to be devoted to analyzing the effects of these distortions.

\section{BASIC DATA REQUIRERENTS FOR COUNTRY STUDIES}

For all countries included in the project, the common data gathering effort will be devoted to obtaining good estimates of the labor inputs per unit of value added in exports, import-competing and non-competing import Industries. ${ }^{1}$ Once those estimates are made, the individual researcher will have to decide, on the basis of his findings and knowledge of circumstances

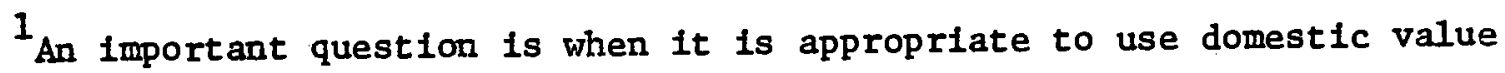
added (DVA) and when International value added (IVA) should be used. In general, domestic values are appropriate for inputs, and international values for outputs, but much depends on what question is being asked. The specification of DVA or IVA in the discussion that follows should be carefully noted. 
In his country, how to allocate his efforts and analyses among factor market phenomena, factors in the trade regime influencing the commodity composition of trade, and estimating optimal trade patterns. In every study some attention to each of these three avenues of Inquiry will be warranted, but the amount of emphasis on each w111 vary greatly from country to country. Each country study w11l thus have at least four parts, which are discussed In tum in this and the following three sections. The basic data described here (and elaborated upon further in Project Working Paper Number 2) will require a falr amount of attention in all the countrles, whereas the relative Importance of the toptcs dealt with in Sections IV, V, VI and VII can vary considerably from country to country.

It will prove useful to all project partictpants if data that are available are presented on a comparable basis in all the country studies. 1 For that reason, Appendix I is devoted to setting up a numbering system for tables and modes of presentation that can be used by all. Concern here (and in PWP 2) is with the substantive issues that arise in collecting, rectifying, and meaningfully assembling data.

Individual researchers will have to make a cholce, at an early stage of their work, even for the basic data requirements set forth in this section: research effort can be devoted to obtaining more disaggregated and better data for a particular point in time, or it can be allocated to obtaining comparable data for a number of time periods. In general, a resolution to that question should depend on the degree to which the

${ }^{1}$ One of the biggest advantages of this approach is that it saves others long searches for data that are, in fact, unavailable. 
findings for the first perlod conform to a priori expectations, on the amount of effort required to obtain each type of data, and on the extent to which meaningful hypotheses can be formulated as to the expected nature of changes that would be observed between perlods. In South Korea, for example, if the employwent Implications of exports, 1mport substitutes for non-natural-resource products, and non-competing 1mports were known for the late $1960^{\circ} \mathrm{s}$ when incentives were blased toward exporting, 1 it would be of great Interest to examine the employment content of the same category of commodities for the late $1950^{\prime} \mathrm{s}$, when incentives were st111 blased toward 1mport-substitution. ${ }^{2}$

In choosing the period of time for which the basic data are to be collected, data avallabllity will usually be the crltical factor. In general, It will be preferable to have trade data, data on the incentives provided by the trade and payments regime, employment coefficients, and factor market data all for the same year. ${ }^{3}$ When they are not all avallable for the same

$1^{1}$ For the definition of blas in the trade and payments regime, see Anne 0. Krueger, Forelgn Trade Regimes and Economlc Development: Liberalization Attempts and Consequences, Chapters IV and VI. Brlefly, the bias in the regime is the ratio of the domestic to international price of the exportable divided by the ratio of the domestic to the international price of the import commodities.

2In addition to substantive interests in differences between periods, obtalning data for adjacent perlods can yield valuable information about the relative stability of different coefficients.

3 Eere and later, I assume that a Census of Ifanufactures is avallable for the same year as the input-output table. If that assumption is not the case, it is probably preferable to employ the year of the Census of Manufactures for most purposes. 
year, choice of a year for which the data are available at closely neighboring periods will probably be the consideration of greatest importance, but the year chosen will almost certainly have to be one for which a Census of Manufactures (or Industries) exists.

In some cases, it may, of course, be possible that the marginal cost of obtaining the time series data will be quite low. In those instances, researchers will be enabled to test additional hypotheses as well as to have greater confidence in their findings.

Trade Data

The first problem is to disaggregate the data to the desirable extent. The desirable levels of disaggregation will depend on the availability of trade data and labor coefficients. Procedures for deciding on when disaggregation has the highest payoff are discussed in Section VI.

In general, trade data are readily avallable and will not constitute a major data obstacle. The only problem, therefore, is to devise a criterion for appropriate classification of industries. If, in fact, goods and factor markets were perfect, the procedure for so classifying would be straightforward. One would separate out trade in natural-resource-based (NRB) 
commodities, ${ }^{1}$ and then divide trade flows of other goods (HOS goods) into those with countries presumed to have more capital relative to labor than the country in question and those with countries presumed to be more labor abundant. In practice, it is likely that most developing countries will have the bulk of their uos trade with developed countries, so that the direction of trade may not be a significant factor and partitioning may be unnecessary. Individual researchers should, at any early stage of the analysis, examine trade flow data to see if the commodity composition of trade with countries presunably more labor abundant differs appreclably from that with countries presumably more capital abundant.

In practice, however, most countries have protected some Industries to enable domestic production to get started. It will therefore be desirable

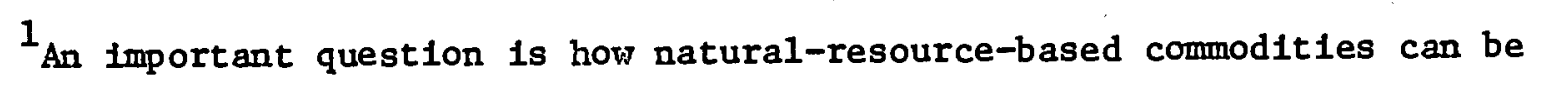
defined. In principle, all one needs do is to define manufacturing as a valueadding activity, and to treat the export of, e.g. refined copper, as an export from two separate sectors: the value of the raw copper would be included as part of the export of the primary sector while the value added in refining copper would be included as manufacturing value added. In practice, some manufacturing operations are location-orlented toward the raw materials source. Researchers will have to use their judgment as to whether a particular manufacturing operation is "raw-materlals-based" or not. Unless the activity is truly tied to the source of raw materials, it will be preferable, as discussed below, to divide manufactures into those with a significant raw materials base and those without. Apart from the question of value added in manufacture, it seems straightforward to treat raw-materials-based industries as those Included under agriculture, mining, forestry and fishing. 
to attempt a four-way classification of HoS commodities: those that are exported, those which are Import substitutes, those which are Imported for which there is no domestic production (1f necessary with an origin breakdown), and home goods which would not be traded with1n the relevant range of possible price variation.

It will probably prove desirable to allocate commodities to varlous categorles at the lowest level of aggregation and then sggregate to twodigit totals for each category. For example, food processing often contalns bakery products, which are usually nontradables, as well as canning industries whose output may be destined for export. Rather than assigning all of that industry initially to one group, it will be preferable to allocate the varlous subcategorles of the industry to their different categories and to treat tradable food processing as a different two-diglt industry from home-goods food processing. 1

It is not possible to provide a classiftcation of commodity categories that should be applicable to all countrles, because the same Industry may belong in different categorles in different countries. For example, printing and publishing is a home good in most countrles, but it is a traded goods industry in Tatwan and Hong Kong.

In general, it will be desirable to regard construction and the various services sectors - transport communication, electricity, gas and santtary services, wholesale and retall trade, finance, Insurance and real estate, and other services - as being home goods. Even then, there are

${ }^{1}$ See below, under "Computation of Factor Proportions" for a discussion of the various types of categorles that may be of 1nterest for each trade classification. 
exceptions as finance is an Important tradable for Singapore and Hong Kong. By and large, disaggregation efforts should be directed toward tradable goods, as home goods sectors need not be disaggregated in most instances. Once the destrable level of disaggregation is reached, the problem is one of deriving a criterion for allocation of commodities, and then of forming meaningful aggregates.

The best procedure is to obtain data for each commodity on domestic production and consumption - Including all intermediate uses of the comodity - for a period of time comparable with the period for which the trade statistics apply. If possible, also, one would obtain these data for a period of several years, and use averages to avoid the influences of timing patterns, inventory fluctuations, and other factors on trade flows. For each commodity 1 , one could then compute the statistic:

$$
T_{1}=\frac{C_{1}-P_{1}}{C_{1}}
$$

where $C_{1}=$ domestic utilization and $P_{1}=$ domestic production, and classify according to:

1 is exportable if $T_{1} \leq x_{0}$

1 is import-competing if $X_{0}<T_{1}<z_{1}$

1 is non-competing if $X_{1}<T_{1} \leq X_{2}$

where $X_{1}^{\prime}$ 's are chosen as cutoff points, which would presumably vary with the level of aggregation. If $x_{0}$ were set at zero, for example, a negative $T_{1}$ would mean the commodity was classified as an exportable. If $T_{1}$ was positive, there would be import-competing production; however, to allow for the possibility that domestic production really represents a nonhomogeneous commodity (as in the case, for example, of repairs which are 
included under transportation equipment), it is suggested that a cutoff point for $x_{1}$ be used. $x_{1}$ might assume a value somevhere between .5 and .99, depending on the homogeneity of commodity categorles and the degree of disaggregation. Finally, when there is little or no domestic production, the 1th commodity can be regarded as a non-competing import, and $\mathrm{x}_{2}$ would usually be 1 .

The fact that the import regime may contain import prohibitions will lead to some modifications of the rules, as can the fact that currencles may be overvalued and exports subsidized. For, when they are, there may be some comodities for which domestlc production equals domestic demand, but which would be exported at a realistic exchange rate, some comodities exported that would not be at a unified exchange rate, and other commodities which might not be produced at all under an efficlent pattern of resource allocation but for which all domestic consumption is satisfled by domestic production as a result of the 1mport regime. In cases such as those, therefore, Individual authors will have to use their fudgment to allocate the comodities among those domestically produced goods that would be non-competing without protection, those that would be competing, and those that would be exportable. While it is impossible to provide adequate guldelines for all cases, one possible criterion for determining whether a particular commodity wight be exported under a more realistic exchange rate would be whether it was, in the past, exported. 1

In many instances, authors will wish to use several allocation rules, and to make their estimates on alternative bases simply to test the

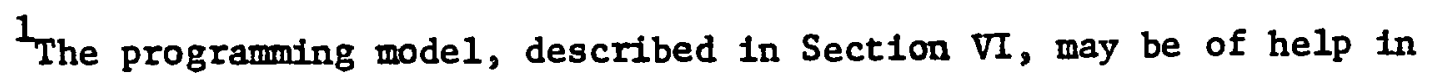
refining the categorles.
} 
sensitivity of their results to their classification decisions. One way would be to classify all commodities on the basis of $T_{1}$ cutoff points deemed appropriate and then to attempt an alternative classification based on the author's judgment (and knowledge of export subsidies, the height of protection, and other relevant variables) as to what commodities would lie In each category under the ideal resource allocation.

Once classification is made, authors may wish to form a number of subcategories. As mentioned above, one might wish to break exportables Into HOS goods and NRB goods, but then further subdivide HOS goods into manufactures where domestic raw-material availability is important (as, perhaps in some metal refining) and others where it is not. Likewise, each major category might be subdivided into trade with developed countries and trade with developing countries. In many cases, it may well be that virtually all Hos-based trade is with the developed countries. In that case, a simple tabular presentation of the percentage of trade in each commodity category with those countries will suffice. In other instances, when trade with other developing countries is important in some HOS goods but not in others, it will prove desirable to categorize comodities, not only according to the $T_{1}$ statistic, but also according to whether the commodity is exported predominantly to developed countries, predominantly to other developing countrles (as, for example, partners in a customs union) or to both. (See Table 1 below.)

Production and Employment Data ${ }^{1}$

As already seen, production data w11 be required simply to compute

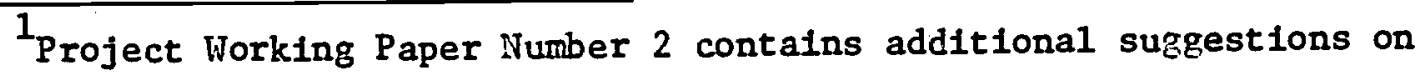
the topics covered here. 
$\mathrm{T}_{1}{ }^{\text {'s }}$ in order to allocate commodities into the appropriate trade categories. ${ }^{1}$ Some data will undoubtedly orlginate from input-output tables, which are discussed in Section VI below. In almost all instances, however, researchers will find it desirable to disaggregate at least some industries below the level found in the I-O tables. For that purpose, they w 111 probably find the Census of Manufactures the document of greatest value.

In almost all cases, the Census should contain data on: 1) value added, at domestic prices, in the activity: 2) purchased Inputs at domestic prices: 3) number of employees in the industry; 4) wage and salarles paid; and 5) payments made for electricity and perhaps other domestic services, Including transportation. Those data will form a basis, when combined with data on the trade regime, for disaggregating the input-output table to the desired extent. 2

Employment Estimates. The most 1mportant use of these data will be to obtain estimates of employment per unit that are as comparable as possible. $^{3}$ A number of issues arise in this connection: part-time versus full-time employment, seasonal employment, the comparability of employees in different activities, and the location of employment.

${ }^{1}$ If separate estimates of domestic consumption of commodities are avallable, they can be used in computing the $T_{1}$. Usually, however, consumption can be calculated as equal to domestic production plus Iraports minus exports.

${ }^{2}$ One problem of Importance here and elsewhere is disparities between firms of different sizes. See Section $v$ below for a discussion.

3 The units are discussed below. 
Ideally, one would wish to measure hours of employment per unit, rather than efther weeks (where hours may vary) or months. In most instances, however, this will prove impossible, and researchers should be alert for such pleces of evidence as will enable them to infer the extent to which their data (e.g., man-years) are blased by non-comparability of days, weeks, or seasons. In some instances, alternative data sources, Including manpower surveys, may enable conversion of "men" Into a more meaningful unit. 1

For present purposes, however, the really critical issue will be the extent to which "labor" is homogeneous. In particular, the entire range of Issues associated with skills is of Importance here. To some extent, the data required here will be needed also in the analysis of factor-market distortions (see Section V), but even in countries where there is no a priort basis for belleving that distortions are significant, some analysis of skill content will be required. A first, and simples statistic will consist of computing wages per employee in different industries when both pieces of data are available from the Census. ${ }^{2}$ Analysis of labor market conditions will be required for proper interpretation of that statistic, but under sultable conditions, industrles paying higher vages per man-hour can be regarded as Industries using more skills per unit of output. Even in countries where

${ }^{1}$ Another Important question vill be the number of shifts employed with given capital equipment and reasons for that number.

2 The wage-per-untt-of-time statistic may be heavily influenced by the extent to which the industry has firns in the large-scale and smallscale sectors. It might be desirable, when that was believed significant, to take the wage ratio separately for large and small firms. 
the labor market does not seem the approprlate focal point for in-depth analysis, researchers should make every effort to obtaln Industry-specific estimates of wages per employee, or some other varlable to indicate the skill requirements of different industries. ${ }^{1}$

Labor Per Unit of What? Assume f1rst that there are no traded intermediate goods, so that there are only domestic (primary) factors of production employed in producing commodities. The question then is whether units should be output at domestic prices or output at international prices. For purposes of evaluating factor Inputs, domestic value added should be employed. ${ }^{2}$

${ }^{1}$ In some countries, of course, there may exist categorization of workers into "skilled" and "unskilled." That statistic should be examined with care when used, and its meaning explained fully. Turkey, for example, classifies something over 70 percent of Turkish workers going to Germany as skilled, while Germany so classifies only about 15 percent of those workers. 2 If the HoS two-factor model were valid, it would make no difference whether domestic or International prices were used because any industry using more labor per unit of output would use less capital. In reality, however, cases are encountered where more capital and more labor are used in one country than elsewhere. Consider, for example, a two-comodity case in which commodity $x$ was protected by a 100 percent tariff, with both commodities having domestic prices equal to one peso, with the exchange rate of one peso equaling one dollar. Suppose, further, that it took 30 centavos of labor to produce 1 peso of $x$ and 50 centavos of labor to produce 1 peso of $y$. The commodity y is clearly labor intensive, in that it would require less labor and more of other resources to produce $x$ and more labor and less of other resources to produce $y$. Consider, now, the ranking at international prices. It takes 50 centavos of labor to produce $\$ 1$ of $y$, and 60 centavos of labor to produce $\$ 1$ of $x ;$ it also takes 50 centavos of capital to produce $y$ and 140 centavos of capital to produce $\$ 1$ of $x$. The point is that the wage is equated in both industrles when equal to domestic price times marginal product. It 18 therefore domestic values that must be employed. 
The reason is that concem here is with employment implications and examination must therefore be focused upon the opportunity cost of expanding one activity or another. Domestic values are the appropriate unit for comparison in that instance.

Even when domestic values are used, there is still a question of how to treat intermediate goods and home goods when the assumption that only primary factors are employed is abandoned. Here, the solution must be to use domestic value added rather than value of output and to include that component of home goods prices which reflects value added in the home goods inputs per unit of output of tradables. The reason for using value added, rather than value of output, is the same as the reason for using effective rather than nominal tariffs: concern is with the employment of domestic resources in value-adding activities. Ctherwise, if value of output is used, an activity with a high proportion of value added to output would almost certainly appear to be more labor (and capital) intensive than another where intermediate goods constituted a very high fraction of product price. ${ }^{1}$ Direct labor requirements, therefore, should be computed per unft of value added measured at domestic prices, where value added is the domestic output price less the cost of all purchased inputs per untt of output. The appropriate concept for direct plus indirect labor requirements should be the direct labor requirements, as measured above, plus the requirements of labor used in home goods per unit of value added, with value added itself

$I_{\text {This }}$ is because both labor per unit of output and capital per unit of output would be likely to be higher in the activity with the high proportion of value added. It would not happen, of course, if capltal-labor ratios were used. 
adjusted to include the prinary factors employed in producing home goods used in producing a unit of domestic currency of output.

Suppose, for example, that a peso's worth of textiles is produced with 30 centavos of cotton (tradable), 10 centavos of electricity and transport (home good), 25 centavos of labor, and 35 centavos to all other domestic factors of production. Suppose further that electricity and transport require 20 centavos of labor per unit of output, and 40 centavos of other domestic factors of production, with no indirect requirements of other home goods. Then, the direct labor requirement per unit of domestic value adjed is $25 / 6$, since 25 centavos is paid to labor and value added is 60. Direct plus indirect labor requirements are $27 / 66$, since there are 2 centavos of indirect labor used in producing electricity and transport, and 6 centavos of domestic primary factors (including labor) exployed in producing electricity and transport services used in producing one peso of textiles.

Given the ambiguity of words when it comes to concepts such as "direct requirements of labor plus indirect requirements in home goods," it may be useful to express the above algebraically. The direct labor requirement per unit of domestic value added in the $j$ th activity, $L_{j}^{d}$, can be computed from data on employment in $j, E_{j}$ (measured in the most appropriate unit avallable, being sure that inits are comparable in different activities), the domestic value of output $\left(v_{f}\right)$, and the domestic value of purchased inputs $\left(\mathrm{H}_{j}\right)$ as

$$
L_{j}^{d}=\frac{E_{j}}{\nabla_{j}-H_{j}}
$$


Indirect labor requirements in home goods ${ }^{1}$ per unit of output of the $j$ th tradables is $a_{j h} \frac{E_{h}}{V_{h}}$ where $a_{j h}$ is the input of home goods per unit of traded goods output. Indirect labor requirements for home goods per unit of value added of the $j$ th tradable, $L_{j}^{i}$, are therefore the labor requirements per unit of output times the ratio of value added to output in the jth tradable. That is

$$
L_{j}^{i}=a_{j h} \cdot \frac{E_{h}}{V_{h}} \cdot \frac{V_{j}-M_{j}}{V_{j}}
$$

Total requirements of labor directly in the $j$ th tradable plus indirect requirements in home goods, $L_{j}^{t}$, are therefore

$$
L_{j}^{t}=L_{j}^{i}+L_{j}^{d}=\frac{E_{j}}{V_{j}-I_{j}}+a_{j h} \cdot \frac{E_{h}}{V_{h}} \cdot \frac{V_{j}-H_{j}}{V_{j}}=\frac{E_{j}+a_{j h} \cdot E_{h} / V_{h} \cdot V_{j}}{V_{j}-H_{j}}
$$

of course, if home goods are an input into home goods, $a_{j h}$ should be interpreted as direct plus indirect use of home goods per unit of tradable and $a_{j h}\left(V_{h}-K_{h}\right)$ should be domestic value added in "direct indirect" plus "indirect indirect" use of home goods."

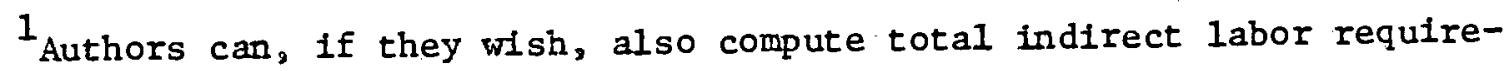
ments (including those emanating from domestic production of import-competing or prohibited - commodities). It is not obvious, however, how that statistic should be interpreted.

2 In practice, it may well be that "indirect indirect" home goods requirements are so small that a single figure can be computed from the input-output table and used for all sectors without any sizable error. 
Once the $L_{j}^{d_{i} s}$ and $L_{j}^{t_{1}} s$ are computed for individual industries, the remaining problem is to form estimates of labor per unit of value added for different commodity categorles, and that requires a weighting scheme. Consider the Ith category, which might be a two-digit SIC category which was to be summed separately for exportables and import-competing goods from the disaggregated data available at the three- and four-digit level. 1 Domestic production is not a satisfactory weight for import-competing commoditles. One must, therefore, use value-added in domestic production plus exports, $x_{j}$, for weights. ${ }^{2}$ Then, labor per unit of value added In the ith category is

$$
L_{1}^{k}=\frac{\Sigma L_{f} X_{f}}{\Sigma X_{j}} \quad k=d, 1, t \quad(4,5,6)
$$

Trade Regime Data

For analysis of the reasons why the labor coefficlents are whatever they are, trade regime data w11l prove essential, and some of these should be regarded as part of the basic duta set common to all country studies. Ideally, one would like estimates of domestic and International prices of all outputs and inputs, so that domestic and Intemational value added per

$1_{\text {For non-competing Imports, of course, the procedure should be the }}$ same as those outlined here, but of course coefficlents will have to be taken from another country's data and adjusted according to the procedure defined in equation 6 below.

${ }^{2}$ In most cases, that will probably mean using American or Japanese data from input-output tables to estimate value-added per dollar of imports. 
unit of output could be computed in all 1ines. ${ }^{1}$ In most cases, however, prior work will have been done on the trade and payments regime, and researchers will probably be vell advised to use that work to the extent possible rather than attempting new estimates.

Effective Protection Estimates. The Ideal set of data would be a set of estimates of effective protection rates (ERP's) appropriately calculated, ${ }^{2}$ on a basis comparable to the individual industry categorles used for calculation of labor requirements per unit of value added. In the absence of distortions, ERP's provide an estimate of the proportionate excess of intemational value added (IVA) over domestic value added (DVA). Researchers will generally find that the avallable estimates do not conform to their classification and w1ll undoubtedly have to devote some effort to providing estimates on a comparable basis. ${ }^{3}$

In addition to estimates of effective protection rates, it will be desirable, in each country study, to have a brief description of the

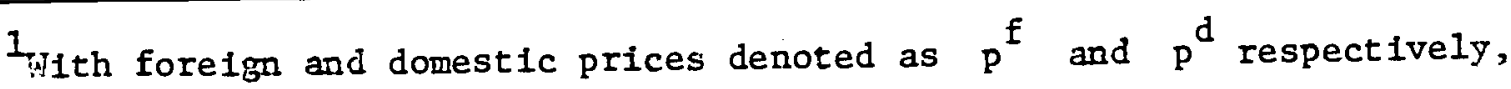
the ratio of international to domestic value of outputs is $p / p$. Internat lonal value added per unit of output of $j$ is $p_{j}^{f}-a_{1 j} p_{1}^{f}$, while domestic value added is $p_{j}^{d}-a_{1 j} p_{i}^{d}$.

${ }^{2}$ See Section IV below for a fuller discussion of ERP's and means of computing them.

${ }^{3}$ In many cases, it will be necessary to assume that all itens in a particular category are subject to the same average tariff on inputs, or otherwise to estimate output tariffs. Sometimes, sectoral ERP estimates will have to be used. Authors should try to avold using these estimates across exports and import-competing subsectors. 
evolution of the trade and payments regime. In many cases, the researcher w111 be able to c1te other work (as, for example, the studies resulting from the NBER project on Forelgn Trade Regimes and Economic Development or the O.E.C.D. studies) and provide a brief synopsis of it. The major purpose of describing the evolution of the regime w11: be to evaluate the environment that determined the commodity composition of trade. For countries where little work has been done, researchers will probably wish to provide a delineation of their country's experience into the phases described in Chapter II of the Krueger synthesis.

Direct Price Comparisons and Tax Treatment. In some cases, authors may themselves wish to construct ERP estimates, to disaggregate available estimates Into subsectors, or to develop data on the protective effects of quotas plus tariffs on individual industries. This w11l prove especially desirable when existing estimates fail to take into account the protective effect of quotas or when the sectoral classification under which ERP's are avallable cuts across categorles of traded commodities.

When quantitative restrictions are important and not included in existing ERP estimates, it may prove desirable to gather quotations on domestic and foreign prices. In general, it will be useful to collect comodity-spectfic data on: 1) the c.1.f. price (although even here the data must be scrutinized to insure that the import has not come from a hIgh-cost source such as a bilateral-trading-agreement partner country) of the commodity; 2) the landed cost of the commodity, inclusive of duties and other landing charges; and 3) the domestic wholesale price of the commodity.

Estimation of the "normal" wholesale margin can usually be accomplished either by using other research results or by examining such 
margins for commodities for which quotas are not imposed. 1 with such estimates in hand, one can then derive estimates of the total nominal protection afforded to a comodity by subtracting the wholesale margin from the wholesale price, and then dividing the wholesale price by the c.i.f. price and subtracting one. The division of the protection into the tariff component and the "premiun" component then follows automatically, as the differential between the c.i.f. price and landed cost represents the tariff protection while the differential between landed cost and wholesale price net of normal margin represents the premium.

Sources of data on individual prices are many, and if the researcher has basic estimates of ERP's at a given level of aggregation, it should be possible to disaggregate wherever data are available, checking to see that disaggregation procedures result in comparable estimates across sectors. Potential data sources include: 1) data underlying the wolesale price index, 2) price quotations reported by Chambers of Commerce or manufacturers' associations, 3) records of 1mport license applications in government offices: ${ }^{2}$ and 4) direct interviews wh large buyers and sellers of the produce. In cases where the product is an intermediate input used directly

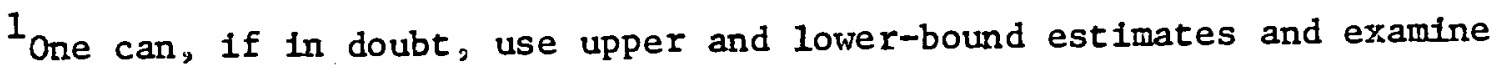
the difference the assumptions make. It is quite possible, of course, that margins are a function of size of shipments, etc., and one might wish an estimate as a function of several variables.

2 There is a question, of course, as to whether license applications contain reliable data. 
by the importer, blacle market quotations are a possible source, although those estimates must be used with care.

One difficulty that often arises in the comparison of domestic and international prices is the problem of taxes. There are four cases. 1). Then a tax is applied to the duty-inclusive price of the Import and to the ex-factory price of the domestic product at the same rate, there is no net additional protection accorded to the firm by the imposition of the tax. 2). When the tax is paid by the domestic firm and not on imported products, that tax represents a partial offset to whatever protection is accorded to domestic producers, and the ad valorem equivalent of the tax should be subtracted from the tariff and the remainder divided by one plus the domestic tax rate. 3). When the 1zport 18 taxed at a rate higher than the domestic product, that represents additional protection to domestic producers, and should be included in the estimate of protection. 4). When a tax is levied on the c.i.f. price of imports and on the ex-factory price of domestic production, the total protection accorded the firn is the tariff rate divided by one plus the tar rate. 1

${ }^{1}$ Let $p_{d}$ be the domestic price and $p_{f}$ the foreign price, with $t$ the tariff rate, $d$ the tass rate, and $d_{d}$ and $d_{f}$ representing tax rates on domestic products and Imports when the two rates are different. Call T the "true" ad valorem rate of protection received by the firm.

Case 1 is then: $d_{d}(1+d)=P_{f}(1+d)(1+t)$, so $T_{1}=t$. Case 2 is: $P_{f}(1+t)=P_{d}(1+d)$, so $T_{2}=(t-d) / 1+d$. For case 3, let $d_{f}>d_{d}$ and $d_{f}=\alpha d_{d}, \alpha>1$. So

$$
\begin{gathered}
p_{d}\left(1+d_{d}\right)=p_{f}\left(1+a d_{d}\right)(1+t) \text {, so } T_{3}=\frac{t\left[1+d_{d}\left(\alpha-\frac{\alpha-1}{t}\right)\right]}{\left.1+d_{d}\right]} \\
\text { Case } 4 \text { is } p_{d}(1+d)=p_{f}(1+d+t) \text {, so } T_{4}=\frac{t}{1+d}
\end{gathered}
$$


Computation of Factor Proportions

Focus in this project is on the employment implications of altemative trade strategies. The theory that can be used to underlie the analysis, of course, is based on labor-capital ratios, rather than on employment per unit of output. In general, however, census and other data will have numbers on wages and salaries, number of employees, and total value added, but not necessarily any independent estimates of capital stock. In such circumstances, the only way to estimate capital requirements directly from those data is to regard that part of value added not attributable to employment of labor as being part of the payment to capital. In that instance, no new information is gained by computing "capital" requirements, and it is recommended that researchers use labor per unit of value added, and wages per unit of value added. For a number of questions, it will be of great use to obtain independent estimates of capital stock, if such are avallable. Even then, of course, there are a host of problems associated with valuation, estimating the flow of services, and so forth. 1

For purposes of obtaining the basic estimates of labor requirements, therefore, it is probably preferable that only data on employment be used. All that needs to be done, for that purpose, is to take the labor coefficients described above, and to compute the labor requirements per

${ }^{1}$ In countries where inflation does not distort the figures too much, depreciation plus interest payments can sometimes be used as a proxy for capital. In cases where the input-output table has capital requirements for a sector, those requirements should be allocated to subsectors in accordance with the ratio of interest and depreciation in the subsectoral average. See Project Working Paper No. 2 for more detail. 
standardized number of currency units of domestic value added in each category. To do that will require multiplying the $I^{\text {'s }}$ of equations (1) through (5) by appropriate deflators from the trade regime data and country trade data to value-added terms. Conversion of labor per unit of DVA to labor per unit of IVA requires knowledge of the ratio of the international value added to the domestic value added. Then, L's can be multiplied by those ratios. 1

Table 1 is intended to provide a sumnary of some of the various aggregates of employment per unit of value added that may be of interest. Naturally, country authors will have examined the labor coefficlents in the Individual industries and attempted to analyze any special systematic patterns that emerge. In so doing, other breakdowns of labor requirements will be of Interest, but the ones listed in Table 1 should be presented, to the extent possible, for all countries. ${ }^{2}$

An Important summary statistic w11l be the net factor content of trade, assuming a shift so that trade is reduced (or Increased) at the margin while leaving the trade balance unchanged. IVA, rather than value of exports and imports, must be used to measure this, as otherwise one might have a reexport industry, with very little value adjed per dollar of exports,

$1_{\text {Authors are asked to check for absolutely inefficient processes }}$ at each stage. It is possible that some import-competing production requires both more labor and more capital than export production per unit of IVA. In that case, labor required per DVA in import substitution could be smaller than in exports, while labor per IVA might be larger. ${ }^{2}$ See Appendix 1 for the suggested ordering of data tables. 
and a million-dollar cut in exports might itself imply a $\$ 000,000$ cut in imports, while a million-dollar cut in imports would, usually, represent a million dollar increase in value added. Thus, reducing exports and imports by one million dollars each would improve the trade balance by $\$ 900,009$, all else equal. In effect, the net factor content of trade is the statistic that is really implied by the fos model: it predicts that a labor-abundant country will be a net exporter of labor and a net importer of capital. One simple transformation of that preaiction is that the country will, on net, export labor.

For domestic value added, there are three important estimates of labor per unit of DVA: that employed in exports, that employed in domestic import-competing production, and that that would be employed if imports vithout domestic competitors had to be produced domestically. ${ }^{1}$ Data for labor requirements and other variables for exports and 1mport-competing goods have already been discussed. For non-competing imports, authors vill probably have to use data from other countries' input-output tables. Thus, if e.g. tractors are imported and not domestically produced, one would have to estimate labor requirements (and other inputs) from another country's input-output table (or Census of ianufactures). Then, one would have to ask how domestic factor proportions might vary from those in the other country. Several means of estimation are possible, and authors will undoubtedly find means most suitable to the circumstances of their country. One possible method would be to take the ratio of the labor input, $1_{j}^{k}$,

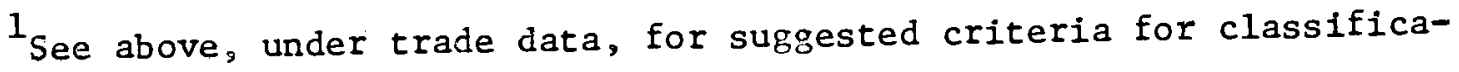
tion of commodities into the desired aggregates. 
in the $j$ th industry in country $k$, relative to the labor input in 1 , where 1 is also produced in country $h$. One could then compute:

$$
1_{j}^{h}=\frac{1_{1}^{k}}{1_{1}^{k}} 1_{1}^{h}
$$

This is tantamount to assuming that the 1 and $j$ industries have the same elasticities of substitution, so that the proportionate change in factor proportions between the two industries is the same in the two countries. Various subcategories of goods within each traded good classification will be of interest. Hithin HOS goods, country authors may wish to distinguish between manufactures where the availability of an intermediate input (such as jute in India) is of great significance, and HOS goods that are "footloose." It will be important, somewhere in the write-up, to explain the basis for this classification, since, as pointed out above, the same Industry may be "footloose" in one country and materials-based in another. It will depend upon the direction of trade whether decomposition of labor requirements into those with higiner labor-capital endowments (LDC's for short in Table 1) and those with relatively greater capital stocks is worthwile. In some countries, it may be desirable to provide such a breakdown for HOS exports and not for NRB exports, and so on (regional trading arrangements may prove important here).

Finally, within import-competing goods, it may prove useful to distinguish, particularly among HoS goods, those comodities which are imfort-competing only because they are accorded protection. As already Indicated, country authors will have to use their judgment to decide whether such a dichotomization is warranted and can be meaningfully made. 
1. Net Factor Content of Balanced IVA = labor per million untts of IVA of exports less labor per million units of IVA of imports.

2. Labor per million of DVA in:
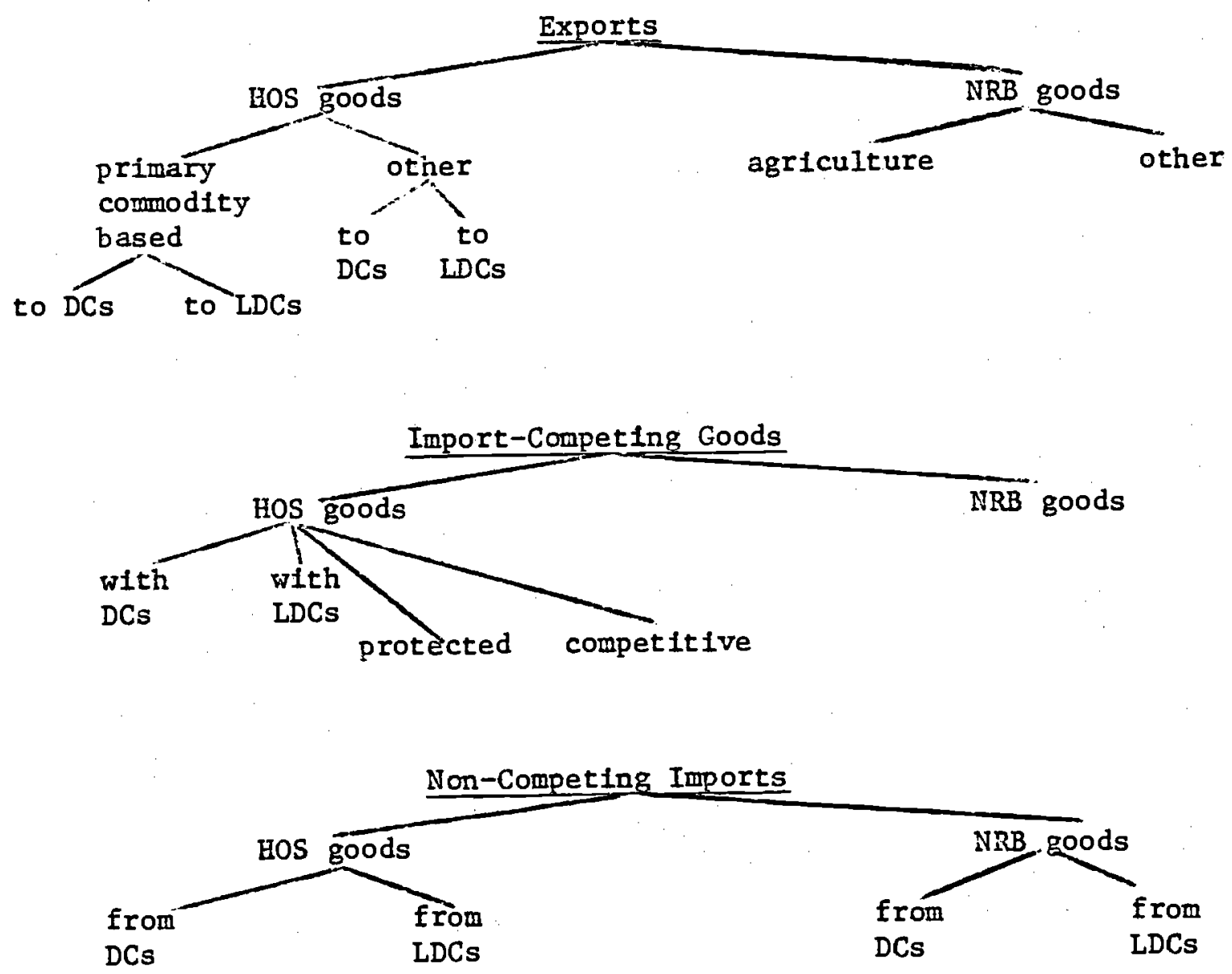

Note: It is anticlpated that each aggregate will be computed for direct labor requirements (Equation 4) and for direct labor requirements in value added in the tradable pius indirect labor requirements in the production of home goods (Equation 6). 
Preliminary Analysis of Findings

The major task in all country studies will be to analyze the findings that emerge from calculating labor requirements per unit of value added in different groups of activities. Each researcher w1ll have to judge, on the basis of his findings and of knowledge of his country's policies and circumstances, where to focus his effort. Possible lines of inquiry are the subject of the next several sections. Here, it should only be pointed out that several tests should probably be conducted for all countries. First, It will be desirable to attempt to estimate statistically the relationship between the height of effective protection and the labor requirements per unit of value added. The hypothesis underlying the factor proportions model of trade, for a labor-abundant country, would of course be that effective protection requilements to induce domestic production would be smaller, the greater the labor requirement per unit of value added. One qualification to this hypothesis would be the assumption that industries are absolutely efficient, and do not use both more capital and more labor per unit of output. ${ }^{1}$

The main task of analysis, however, will be to interpret the findings carefully, particularly with regard to approprlate categorizations of Industries, and to determine the amount of research effort to be allocated

${ }^{1}$ Since this working paper was written, it has become apparent that the hypothesis of a link between factor proportions and the helght of ERP's Is meaningful only if it is posited that there are no monopoly profits resulting from protection. If tariffs confer monopoly powers in the domestic market, then a much more complex hypothesis must be formulated. 
to each of the three possibilities: 1) factor market distortions significantly affect the coefficients: 2) the trade regine itself significantly alters the commodity composition of trade; and 3) domestic markets are so imperfect that simulation methods must be used to Investigate what would happen in an efficlent allocation of resources.

Summary of Basic Data to be Presented

Insofar as possible, each country study will contain: 1) a description of the evolution of the trade and payments regime, with estimates of the effective protection accorded to the various industries at the same level of disaggregation as the input-output table: 2) a categorization of commodities, disaggregated from the input-output table along the lines indicated in Section VI, into the relevant categorles of NRB tradable, HOS tradable, and home goods, with approprlate further breakdorns; 3) an estimate of labor requirements, standardized Insofar as posstble with respect to skills and hours of work, per dollar of domestic and intermational value added, for each comodity category; and 4) estimates of the labor requirements per million units of domestic and international value added in the various aggregate categories of tradables. ${ }^{1}$

These data will enable some preliminary analysis of the link between alternative trade strategles and employment, and they will also provide the basis on which allocation of effort among alternative lines of investigation can be made. In addition, of course, they will yleld a set of data common across the countries, in spite of their diverse circumstances. There are many ways, even at this preliminary stage of basic data, in whtch authors

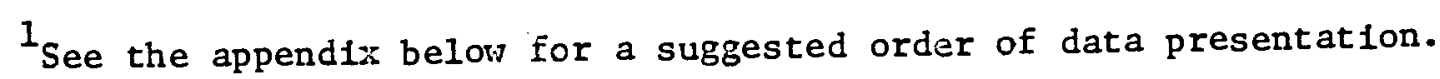


will find it possible to enrich their findings: examination of time series patterns, use of independent capital stock data, alternative categorization of commodities, and so on. What has been presented here should be regarded as a minimum, about which each researcher can use his own judgment as to how best to proceed to analyze the reasons for his findings.

\section{ANALYSIS OF THE TRADE REGIME AND ITS EFFECTS}

There are two Important ways in which the trade regime can Influence the empirical findings. First, in a variety of ways, the regime can directly influence the composition of the varlous subcategorles of tradable goods. Secondly, the regime can affect the prices of factors of production, and thus alter the profitability of alternative activities and the factor proportions used in them. General equilibrium considerations tell us that these two avenues are bound to interact, but for research purposes it will be necessary to treat them separately empirically.

It should be noted that each trade regime interacts with domestic varlables in a varlety of Important ways, and the same trade policy can have totally different effects depending on the domestic context. Moreover, the variety and combination of possible policies and effects is virtually Infinite, and all that can be done here is to raise some considerations of the sort that will have to be analyzed in the country studies. Questions that w111 have to be considered, to greater or lesser degree, In each study, include the following: 1) To what extent could alterations be made within the same trade strategy that would further the employwent goal? 2) To what extent does the trade strategy itself affect the factor intensity of exports and Import substitutes? 3) To what extent would alteration of the 
trade strategy significantly affect employment (other than via its effect on the overall growth rate)? Naturally, in countries where it is found that exports of HOS goods are capital-intensive (as Diaz suggests, in his NBER study, is the case for Colombla), analysis will have to be addressed to the question of why that is so. In cases where the exployment implications of alternative trade strategles appear to be approximately equal, attention will focus on those aspects of the trade regime and factor markets that could affect employment in exports and in import-substitution. Finally, In those instances where exports appear to be significantly more labor-using than import substitutes, the question as to whether future expansion will continue that trend, and the scope for increasing further yet the (economic) use of labor will be the focal point of examination.

\section{Effective Rates of Protection}

As mentioned in Section III, 1 t will be necessary to obtain estimates of effective rates of protection (including the value of non-tariff barriers) for the same comodity classification as is used for the labor coefficlents. In the event such data do not already exist, authors wll have to devote a considerable portion of their attention to obtaining them.

The basic data required are domestic and international prices. In instances where tariffs (and other charges translatable into tariff equivalents) are the only form of protection, it is relatively simple to compute the statistic:

$$
E R P_{j}=\frac{t_{j}-\sum_{j 1} a_{i}}{1-\sum_{1} a_{j i}}
$$


where all international prices are normalized at unity. In most instances, it will be most convenient to keep input-output tables at domestic prices, and simply provide estimates of effective protective rates.

When data on tariffs are available (and if they are the only barrier to trade) the only task will be to compute the ERP's and then to transform them from commodity estimates to sectoral estimates in confunction with the Input-output table. In the individual studies, ERP's should be reported at the same level of disaggregation as the employment statistics, since it is those figures which w11l be used to test the hypothesis that higher ERP's are associated with more capital-intensive industries in labor abundant countries. For purposes of aggregation, it will probably be best to use the international value of domestic consumption as weights.

In most countries, however, tariffs do not constitute the only form of protection, and a major challenge is to determine the tariff-equivalent of quotas and other protective devices. Obtaining direct price comparisons is the most satisfactory means of surmounting that difficulty, but it is extremely time consuming if a prior study is not available. In cases where prior studies are not avallable, authors may have to supplement tariff data with some crude categorization of commodities. For example, it might be that there was a group of goods whose importation was freely permitted, another group where $Q R^{\prime}$ 's led to moderate premiums, and another group of commodities whose importation was prohibited and whose domestic prices were greatly in excess of world prices. In such a case, the tariff rates could be used for the first group of comodities, the tariff rates plus $x$ percent could be used for the second group, and an even higher rate, $y$, could be used for the third group. If avallable, additional information (such as the rate of increase of price domestically after import prohibition 
relative to the rate of inflation of the world price) could be used for finer subdivisions. On occasion, researchers will be forced to omit some aspects of the protective structure. In such cases, it will be important in the text to make clear what aspects of the trade regime have been captured in the ERP estimates and what have been omitted.

Impact of the Trade Regime on the Commodity Composition of Trade

As shown in the "Growth, Distortions, and Patterns of Trade Among Many Countries" paper, across-the-board trade policies can influence the amount of trade, and they can render it profitable to produce and even export a commodity that would othervise be entirely imported (an import substitute). Elowever, as long as trade interventions are uniform, it could not be the case that some compodities that were exported lay further away" from the commodities with comparative advantage than others that were not. If, for example, country A extended a uniform export subsidy of 50 percent to all commodities, and that 50 percent translated into the same effective protective rate for all commodities, it could happen that country $A$ began exporting commodities $x, y$ and $z$, not previously exported. Fovever, in this case, one could infer that $x, y$ and $z$ were "next in line:in comparative advantage - i.e., that there were no other comodities closer to comparative advantage. Of particular relevance in the context of examining the employment implications of alternative trade strategies, if the factor proportions explanation of trade vere correct and country A vas very labor-abundant, then there would be no more labor intensive commodities than $x, y, z$ and the commodities previously exported. If one found such commodities (and could reject transport costs, or other obvious explanations for them), it would constitute a fairly convincing refutation of the applicability of 
the factor proportions explanation of trade. Thus, across-the-board protection of import-substitution industries or encouragement to exports should not significantly affect the factor proportions found when examining the labor requirements of various categories of tradables.

If, however, incentives are not uniform, it is quite possible that the nature of the incentives provided by the trade regime can significantly alter the employment implications of exports and import-substitutes. ${ }^{1}$ If, for example, export subsidies are accorded only to "modern," or "Importsubstitution" firms, it might well be that the only activities eligible for the subsidy were far away from the country's "true" comparative advantage.

Country analysts will have to examine their country's trade regime with respect to the hypothesis that the regime itself influences the commodity composition of trade. In cases where there is reason to belleve that it does so, the natural procedure will be to compute the "average effective exchange rate for exports, dollars (or other unit) of exports of commodities which recelve the average rate, and to calculate separately the labor requirements for those exports recelving above-average protection (subsidization). The same sort of procedure can be followed on the Import side, when it is belleved that "natural" Import-substitutes would compete under an efficient allocation: one can compute the average effective protective rate, and then compute the labor requirements for all industries subject to that rate (or less) and then

Hote that we are here assuming that the labor-capital utilization In each activity is given; later, substitution possibilities, especially as influenced by the trade regime, are considered. 
compare that figure with those industrles receiving above-average effective protection.

Along this line, it is important to distinguish between exports that are essentially temporary in nature and those that are of longer duration. For example, it may pay firms at existing subsidy schemes to export out of excess capacity, but not to invest in additional capacity for purposes of expanding their export markets. In these instances, the exchange rate is usually sufficiently overvalued and there are expectations of further overvaluation, so that it does not pay to base one's plans on the export market; an alternative version is that incentives to undertake additional import substitution ventures are sufficiently strong so that all investible resources go to lines where protection $\mathrm{w} 111$ be avallable. This "excess capacity" type of exporting is particularly common in countries with overvalued exchange rates and "made-to-measure" export subsidies to new industries. In those cases, one sort of test that can be made is to examine changes over time in the commodity composition of modern exports: In general, one does not observe sustained growth of most commodity exports. Rather, the phenomenon is that an item enters the export 1 ist for several years, perhaps even increasing in volume for a year or two, but then diminishes again. The small volumes and dispersions of these types of exports, as well as their erratic performance, are both hallmarks of the "excess capacity" type of exports. In most instances, some of the "export" industries are really import-substitution endeavors, and of ten ones where the size of the domestic market was overestimated.

Since the "excess capacity" type of export is not the sort of commodity that would develop into successfully growing exports under an export promotion strategy, it is especially important that country analysts 
examine the determinants of manufactured exports very carefully in countries where Import substitution has been the dominant strategy. In those cases, the hypothesis that the sorts of commodities exported are really import substitutes, and not the sort of exports that would develop under an alternative strategy, may well be of Importance.

There are, of course, even more ad hoc interventions which can affect the comodity composition of trade, and analysts should be on the alert for them. For example, there are countries which prohibit imports of commodities once domestic production has started, but which also 11cense investment. In some Instances, such as in India, firms have had to agree to export some of their output as a precondition for recelving an investment (or a capital goods Importation) 11cense. In those cases, exports are genuinely the (not necessarily profitable) cost of entering the highly profitable sheltered domestic market. To conclude that those commodities represent the sorts of goods that would be exported under an alternative trade strategy would be highly misleading.

In cases where the trade regime has rendered import substitution highly profitable relative to exporting, it may well be that the analyst concludes that prevalling export lists, espectally of manufactured commodities, provide little or no clue as to what would happen under an export strategy. In such instances, analysts w111 surely wish to concentrate some of their energies on obtaining data for simulation of optimal patterns of resource allocation, along the lines suggested in section VI below.

\section{Impact of the Trade Regime on Factor Proportions}

Regardless of whether export promotion or 1mport substitution is emphasized, many of the instruments used to foster that strategy have 
Implications for the relative profitability of alternative production techniques. It is easiest to consider the sorts of influences of the two regimes separately, as they are somewhat different.

Export Promotion. The techniques used to encourage exports not only influence which commoditles are exported but also may affect the factor prices at which potential exporting firms can obtain inputs. There are numerous schemes which enable exporters to obtain intermediate goods at world market prices. These schemes can potentially affect the choice of technique, and hence the employment impact, by making materials-saving more or less profitable. ${ }^{1}$ In most instances, however, it is doubtful whether this effect is significant, and it will probably be best in most studies to note any such schemes chiefly with a view to examining their value as an incentive to exports, rather than for any influence they have on techniques chosen.

Some sorts of incentives for exports - cash subsidies, special exchange rate categories, and so on - can affect the comodity composition of exports as noted above, but need not have any effect on the techniques chosen withln commodity categorles. There are, however, other sorts of

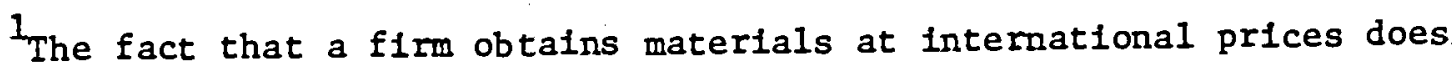
not prove they are cheap if those materials can be resold on the domestic market at higher prices. In some instances, as with the Korean wastage allowance which enables firms to import about 25 percent more than the inputs needed for export, it is precisely the excess of domestic over international value of the materials that provides the export incentive. The value of such schemes must, of course, be regarded as part of the incentive (and effective exchange rate) provided to exporters. 
schemes, especially those concerned with provision of credit or exemption from duties for Importation of capital goods, which can influence the techniques chosen. If, for example, exports are encouraged via the provision of credit at subsidized interest rates for acquisition of capital goods, that provision will have the most significant effect on firms which employ capitalIntensive techniques and on firms which can choose capital-intensive techniques of production. ${ }^{1}$ It is thus in the sorts of export incentives which aim at altering the price of capital goods or services relative to labor that analysts should look for the Impact of the export incentive measures on cholce of technique.

Import Substitution. In the case of import-substitution strategies, a number of systematic tendencies have been observed which tend to render capital cheaper to import substitution firms relative to what it would cost under an optimal resource allocation strategy. When capital is cheaper, of course, there must be some form of capital rationing across firms, and it is Important to distinguish between the nominal price and the effective price to those recelving the credit. If, for example, each firm receives a lumpsum allocation of subsidized credit, but borrows additional finds at the prevailing (market) Interest rate, it is not necessarily so that the choice of techniques will be affected. If, however, firms subject to the capital Incentives are able to obtain all the capital they wish at those prices, while other sectors are confronted with higher prices, the incentive effects can

\section{${ }^{1}$ Likewlse, if exporters are granted the right to Import capital} goods at preferential rates, the same analysis would hold. In general, such is not the case, although potential exporters might be allotted a higher fraction of their Import license applications. 
be highly significant. It is important, therefore, for analysts to distinguish whether schemes that subsidize the use of capital enable some firms to satisfy their demands at the prevalling subsidized prices. ${ }^{1}$

A large number of separate factors have been 1dentifled in importsubstitution regimes that can implicitly subsidize the use of captital relative to labor for firms fortunate enough to recelve licenses. First, the exchange rate itself can frequently be overvalued. In such circumstarces, the authorities are often reluctant to impose tariffs and surcharges on Imports of capital goods, and those commodities are imported at effective exchange rates well below those used for other commodities. Thus, those firms which do recelve fmport licenses for capital goods are fmplicitly subsidized by the amount of the overvaluation of the exchange rate per dollar of license recelved. In some cases, duties and surcharges simply are not applied to those categorles of transactions; in other cases, duties and surcharges are rebated for firms investing in industries to be encouraged by the trade and development strategy. In all studies, analysts will wish to examine the nature of the 1mport regime for capital goods, and the criterla by which scarce forefgn exchange for imported capital goods is allocated. In most Instances, it will be desirable to estimate the percentage Implicit subsidy on use of capital goods. ${ }^{2}$

${ }^{1}$ If, for example, a would-be entrepreneur knows that he will either be able to get the necessary licenses and credit (at subsidized rates) to build a factory, or he w111 be rejected completely, then he is, in effect, confronted with a subsidized price of capital goods and it will pay him to propose more capital-using techniques than if he had different expectations. 2 Where this appears important, authors may wish to go even further in the analysis. Two interesting studies, which may suggest useful Iines of research, are those by McCabe and Michalopoulos and by Ongut, cited above. 
In addition to implicit subsidization through fallure to impose or levy duties and surcharges, there are often schemes for financing capital goods imports of the desired kinds through subsidized interest rates. In such cases, the value and impact of those incentives should be computed in much the same way as in the case of export promotion regimes.

Authors will need to examine the particulars of their trade regimes with an eye to identifying and quantifying those aspects of the regime that influence the choice of technique in particular production lines. In cases where there is no basis for belleving that there are domestic factor market distortions, it will be possible, after estimating the impact of the trade regime on factor prices, to move straight to examining the impact of those factor prices on employment. In most instances, however, authors will wish to consider the effect of domestic factor markets on choice of technique and commodity composition of trade. That is the subject of section $V$.

\section{v. ANALYSIS OF FACTOR MARICETS AND SKILL REQUIREMENTS}

There is no such thing as a perfectly functioning market. However, In many instances markets function sufficiently well so that one can reasonably conclude that prices reflect private opportunity cost: empirical criterla Include the absence of significant excess demand or supply at prevailing prices, the reflection of shifts in excess demand in price movements of the appropriate sign, and so on. Of course, these tests are not perfect, and must be nade with care: a rational employer can pay aboveaverage wages in order to try to obtain better qualified, or more eager, workers. Llkewlse, Individuals may apply for fobs for which they are not qualified. Different wages may reflect different skills, or, for that 
matter, different costs of alternative types of employment. For example, some have argued that the frequently-observed differential between rural and urban wages reflects an imperfectly-functioning market, and a "distortion," while others have argued that higher urban wages simply reflect the greater costs associated with urban living in the form of roads, sewers, housing, and other infrastructure types of investments. ${ }^{1}$

In many developing countries, however, there is ample reason to believe that significant factor market distortions exist, and may well influence the comodity composition of trade, as well as employment per unit of output in different activities. In all country studies, authors will wish to report on factor market conditions, and also to examine, at least briefly, the skill requirements per unit of exports, of import substitutes, and also perhaps of non-competing imports.

There are really different hypotheses underlying the interest in factor markets and in skills, but examination of either will require attention to various labor market phenomena, and therefore will cover some of the same data. In this section, the sort of approach that can be used to examine each of these issues is outlined in turn. As with other topics, the amount of attention given to factor markets will depend on the author's judgment of its inportance in his country. As already indicated above, in all countries it will be desirable to obtain at least a crude indicator of sk11l requirements for alternative activities. In addition, it will be useful to provide a time series on the real wage rate prevailing vithin manufacturing, computed

$1_{\text {See Amartya Sen, Eipploysent, Technology and Development, Clarendon }}$ Press, Oxford, 1975, for a discussion of these and related 1ssues. 
both in domest1c currency units and in U.S. dollars, and also the real price of 1mported and domestic capital goods, for each country. The extent to which authors go beyond that w111, however, depend on their interpretation of the data.

\section{Factor Market Distortions}

As shown in "Growth, Distortions, and Patterns of Trade Among Many Countries," the existence of inappropriate factor prices can have Important consequences for the commodity composition of trade and the factor proportions used in particular industries.

The fact that currency overvaluation, failure to impose duties and surcharges on imported capital goods, and interest subsidies can lead to relatively low prices of capital goods was already mentioned in Section IV. In addition, there are numerous cases in which there is reason to belleve that domestic phenomena, including government legislation as well as trade union agreements, can Influence the real wage. Both of these phenomena tend to result in a higher wage-rental ratio than would exist at shadow prices and in theory, it is possible that they can result in the wrong commodities being exported, as well as in the use of more capital-intensive techaiques of production than would be optimal.

The trade regime data contained in the country studies will enable estimates of the real price of Imported capital equipment. In addition, it w11l be desirable to estimate the fraction of capital goods that are domestically produced, and to construct separate real prlce series for construction and for machinery and equipment. 1

${ }^{1}$ For an example of such a series, see Anne 0 . Krueger, Forelgn Trade Regimes and Economic Development: Turkey, NBER, 1974, Pp. 234 ff. 
Some analysis of labor markets should also be undertaken. In particular, authors should examine the extent to which there is reason to believe that the real wage is above its equilibrium level, and the determinants of any distortion in the labor market. Insofar as possible, this should be done by relying on studies already undertaken of labor ma:ket behavior.

Several questions are of importance: 1) what is the phenomenon that gives rise to the distortion; 2) what sector or sectors of the economy are affected by $1 t$, and 3) how significant is 1 t? The questions are interrelated, of course, but it is useful to consider each in turn.

Analysis of the phenomenon that gives rise to the distortion will require care. If legislation is the source of the discrepancy, an important question is the degree to which that legislation is enforced and the sectors to which it is applicable. In many countries, for example, legislation confers senfority rights and sizable fringe benefits upon workers after they have been employed for a specifled period of time. ${ }^{1}$ Insofar as firms' labor requirements are really for unskilled workers, labor turnover can be used as a means for avolding much of the impact of the legislation: when, however, skilled workers are required, such legislation will make firms reluctant to expand employment for fear that falling sales will result in bankruptcy. Another form of labor-market "distortion" arlses when the conditions of employment differ vastly between the large, organized manufacturing sector, and the "Informal" or small-scale sector. There are a large number of important questions about the reasons for differences observed between the

${ }^{1}$ In this regard, it is extrenely important that end-of-year, and other, bonuses, as well as fringe benefits be included in wage rate calculations. 
two. Hypotheses abound: 1) wage differentials between the two sectors represent different skfll attributes on the part of workers in the two sectors; 2) the wage in the large-scale sector is union- or governmentdetermined, while vages in the small-scale sector reflect opportunity cost of workers: 3) workers gain experience in the informal sector and then become eligible, and search, for jobs in the large-scale sector; and 4) jobs in the two sectors draw upon non-competing groups in the labor force. In attempting to draw inferences about factor market distortions, and especially about conditions in the large market, it will be necessary to deal with the large-scale, small-scale phenomenon with some care. In general, it may prove useful to partition data into the two sectors as much as possible, making inferences about the comparability of labor between sectors only when unavoidable or on the basis of past research into labor market conditions. 1 The second question, identification of the sector or sectors that are affected by a wage distortion, is of equal importance. To constitute a distortion, a wage difference must not be based upon cost differences or different productivity. of workers (due to education, experience, or other factors). If a distortion arises between industry as a whole and agriculture, the choice of technique within each manufacturing industry will be affected, but it is not possible that a "reversal" of industries will occur. If, however, the distortion is between manufacturing industries, it is possible that "reversals" in factor intensities, along the lines

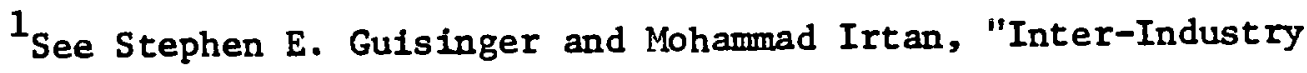
Differentials in Wages and Eamings in Pakistan's Manufacturing Sector," Pakistan Development Review, for an interesting attempt to analyze sources of wage differentials. 
described in "Growth, Distortions, and Patterns of Trade Among Many Countries" will occur. Authors are referred to that document for analysis of cases, and should examine their countries' labor markets with care to ascertain the precise nature of the distortion, and thus to define and limit the sorts of effects that can arise.

In this regard, it is expected that a researcher undertaking one of the special studies in the project will use the labor and capital coefficients, and wage-rental data, to provide estinates of production functions for various industries. Authors will then be able to use those estimates to provide a quantitative indication of the extent to which factor proportions might differ with differing wage-rental ratios. ${ }^{1}$ Details of that procedure will depend in large measure on the preliminary results obtained in the country studies and in the production function estimation. Regardless of the extent to which such methods prove fruitful, however, analysis of the sources and nature of the distortion will be of great importance. Answers to the first two questions - the source of the distortion and the sectors affected by it - will al ready provide some indications of the significance of the distortion. In some countries, authors may conclude that, for example, minimum wage legislation was insufficiently enforced or had enough loopholes so that the effect on real wages, and thus on the profitability of labor-intensive techniques, was relatively minor. In other

${ }^{1}$ See Section VI below. It is anticipated that the optimizing special study will provide estimates of shadow prices of factors which may be useful for estimating the employment losses associated with subsidization of capital and with raising the real vage. 
cases, however, authors may wish to examine the hypothesis that the combined effects of above-opportunity-cost wages and subsidized capital significantly affected either the cholce of technique or the commodity composition of output and trade. It is impossible to anticipate all of the posstble avenues of research that might be explored when this hypothesis appears plausible. In some countries, It may be possible to provide estimates of the urbanrural wage differential and of urban unemployment rates. In many cases, the real wage and rental prevalling for manufacturing industries can be contrasted with estimates of shadow prices that are computed out of the optimizing models described in Section VI. However, individual researchers will have to use their judgment both in deciding on the relative importance attached to analysis of factor market distortions and their influence on the commodity composition of trade and factor proportions employed and on the means to be used to estimate the quantitative magnitudes of the distortions and their effects.

$\underline{\text { Human Capital }}{ }^{1}$

If one is to attempt to estimate the employment Impact of alternative trade strategles, it is not enough to count the "number" of workers. It is widely recognized that human belngs do not constitute a homogeneous mass of employable laborers and that skills and training are important inputs in the production process.

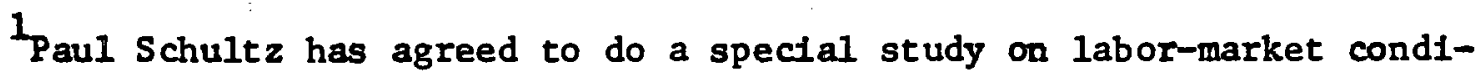
tIons and the human-capital questions involved. His work may provide additional Insights of use to country authors at later stages of the research. 
There are many important and uranswered theoretical and empirical questions about the role of skills in determining comparative advantage. Of great importance is whether skilled workers are complementary to machines or whether skilled and unskilled workers are close substitutes; antithetical to either of these hypotheses is the notion that human capital (or skills) is a separate factor of production, and the skill requirements per unit of output are uncorrelated with either capital or labor requirements. If either of the former hypotheses is correct, the factor proportions explanation of trade would not be seriously impaired, as one might safely infer that countries with relatively poor endowments of capital also had relatively poor endowments of human capital. If, however, the skill, capital, and labor requirements were uncorrelated, any explicit statement of a factor proportions explanation of trade becomes extremely difficult.

One partial means of getting at this question will be to attempt to estimate the skill requirements in various industries. As indicated in Section III, a simple technique will be to estimate, and attempt to interpret in light of conditions within the country, the average wage per employee in different lines of endeavor once standardization for size-of-firm and other varlables has been accomplished. In many countries, however, authors will be able to find manpower studies, census tabulations, previous research, or other material that will enable them to provide better data. In particular, It will be useful to ascertain the fraction of workers with elght or more years of schooling in each industry, as well as finer education breakdowns 
1f these are available. While occupational category breakdowns can sometimes be of help, they should be examined with great care. ${ }^{1}$

By and large, the extent to which authors examine the skill implications of alternative trade strategies will depend on the avallability of past studies of trade regimes, and of other data necessary for the basic estimates, as well as on their access to reliable data on skill requirements and the human capital composition of the labor force.

In addition to examining the basic skill composition and requirements of various industries, authors should examine the hypothesis that firms are employing overly skilled and trained workers in various occupations. This hypothesis has been put forth several times. There are two variants, and country authors will wish to consider each in light of their findings with regard to general conditions in the labor market. The first variant is simply the stralghtforward hypothesis that, when minimum wage legislation is in force, it will always pay employers to shift their employee composition to a higher level of skill attalnment than would prevall in the absence of the minimum wage. This hypothesis in effect asserts that more highly trained workers are always more productive than less highly trained workers so that, as the minimum wage rises, it pays to hire more skilled workers. The second varlant of the hypothesis is that government education policles regult in an oversupply of college graduates and other highly educated Individuals. These Individuals, so the argument goes, compete with

1 There are handbooks of "manpower requirements" in different Industrles. Authors should be on the alert to avold estimates of skill content of occupations that in fact have been derived from international estimates. 
Individuals of lesser training for available jobs, and so on down the line. In those cases, firms end up hiring individuals of above-requisite training for virtually all positions.

The empirical implications of the two alternatives are quite different. In the first variant, one would find unemployment concentrated in the unskilled occupations (or find a significant wage differential between unskilled urban and unskilled rural workers). In the second, one would find a low rate of return to higher education, and perhaps unemployment among the more highly educated. Even if sufficient resources are not avallable to distinguish between the two hypotheses, it will be important for country authors to provide their judgment as to whether skill coefficients of the various industries reported in their studies are significantly affected by labor market imperfections or not.

\section{THE DETERMINATION OF EFFICIENT PRODUCTION AND TRADE PATTERINS}

The potential employment effects of altemative trade strategies could be investigated most fully were it possible to determine where comparative advantage would lie under conditions of free trade. The determination of such efficient production and trade pattems is the subject of a special study that will be performed by James M. Henderson of the University of Minnesota. His analysis will be within a programming framework (with some nonlinear relations) with a basic model that is both relatively simple, so that it can be implemented with the individual country data, and flexible, so that it can be modified to meet the needs of individual country authors.

This research w1ll involve close cooperation between Professor Henderson and the country authors. A country author may, if he deems it 
appropriate, obtain the requisite data for his country and convey it to Henderson. Henderson will obtain programming solutions with a specially designed computer program, and return the output to the author. The author can then evaluate the solutions in terms of their realism and relevance for his country. If he deems modifications necessary (and first results are almost always only partially satisfactory), the model will be altered accordingly and the process repeated. In the final step, the country author will be able to use the information provided by the solution to the model In Interpreting the divergence, if any, between actual and optimal trade patterns for his country.

This section contains a brief description of the model, and the data that will be needed for 1t. Project Working Papers No. 2 and 3 provide more detalled descriptions.

The basic programing model is rather simple, though it can be extended as far as clrcumstances warrant. Gross Domestic Product, In International prices, is the primary objective function to be maximized. In this context home goods will be treated so as to reflect the International values of their Inputs. A number of constraints will 11mit the levels of income and production. Limited quantities of labor and capital are obvious constraints. Constraints upon the outputs of Individual sectors will reflect capacity limitations upon the intersectoral transfer of resources. Production will obey the fixed-coefficlent input-output assumptions.

It is hoped that, at a later date, the fixed-coefficlent assumptions can be relaxed for labor and capital in another special study that would provide production function estimates to simulate substitution in response to potentlal factor price changes. Thls step, however, must awalt preliminary results. 
A solution for the programing model will provide the output and trade levels for each sector that would be realized under free trade if the technological and other assumptions of the model are fulfilled. The great value of such solutions normally lies in the indication they provide as to where comparative advantage lies rather than in their particular numerical estimates.

The programing solutions also provide shadow, sometimes called eff1clency, prices for labor and capital. In addition, rents for output capacity limits are generated. These are the amounts by which maximal income would be increased if capacities were increased. From a practical viewpoint the capacity rents provide information of particular value with regard to the benefits of potential investment and expansion. The shadow prices for labor and capttal should be useful for country authors.

A great number of extensions and variations of the bastc model are avallable to modify and extend the programming analysis. It will be possible to compute time paths of output and trade with capital accumulation if sufficlent data are avaflable. Some nonlinearities can be introduced if appropriate. Constraints to represent ad hoc interventions in factor markets can be introduced. The effects of foreign aid can be determined.

The data described in Section III will in many cases be useable for the programing model. In fact, all of the data used for the programing also will have other uses. One or more input-output tables will provide the focal data. If a country has no input-output table, or has a highly aggregated one, the programoing analysis may not be possible. Unfortunately, there are a great many differences between the input-output tables of different countries, and the data adjustments for each country will be dependent upon how its table was constructed. Adjustments for a varfety of 
features of Input-output tables are described in Project Working Papers Wo. 2 and 3. A few general observations are given here.

Input-output tables are constructed in both purchasers' values (Including trade margins and transportation) and producers' values (f.o.b. plant). Purchasers' values are preferable for trade analysis. However, most tables are in producers' values. It is normally not desirable to convert to purchasers' values. The producers' value tables show large exports for the home goods trade and transportation even though trade and transportation themselves are not exported. Interpretations of these tables must take account of these constructions.

Input-output tables are given in terms of domestic values for a selected base year. In effect, this procedure defines all domestic prices as equal to one, 1.e., the quantity of a sector's goods that could have been purchased for one untt (or one million units) of domestic currency during the base year. The Project research program requires international prices on a comparable basis. In trade analysis it is customary to let international prices equal one and then define comparable domestic prices as being greater than one. For present purposes, it will prove convenient to reverse the procedure by letting domestic prices equal one, and defining comparable international prices as being less than one. This eliminates the necessity to adjust the input-output table values.

The employment coefficlents described in Section III can be used with the input-output data which describe factors in terms of value added. Imports are handled in a variety of ways in input-output tables. In most cases it will be necessary to disaggregate import aggregates. Secondary products and other 1tems w11 require special treatment for some input-output tables. 
The number of sectors into which the input-output tables are aggregated varies widely from country-to-country. Some tables have as few as three sectors; others have hundreds. A two-digit breakdown for manufacturing and a one-digit breakdown for other sectors or something close to $1 t$, provides a common sectoral classification. There is no classification that is correct for all countries. First, the classification to be used for a country will depend upon how its input-output table was constructed. Second, every country author will desire to disaggregate some sectors of particular significance for his country along the lines suggested in Section III and PUP 2.

In micro analyses one can concentrate upon individual conmodities. In general, studies of the type described here, the sector is the unit of analysis. Therefore, it is desirable to have sectors that contain similar (for the purpose at hand) comodities. The following general considerations may be helpful in determining when disaggregation is desirable:

(1) An important industry has been combined with unlike sectors. Disaggregation using Census and other data w1ll be desirable. In sone cases, cooperation among country authors can allow the use of data ratios from one country to help provide missing figures.

(2) A case in which import and export goods are aggregated in the same sector. Criteria for this case were given in Section III. Important information is lost by a consideration of such sector's net trade, and again, disaggregation is desirable.

(3) Two or more industries with substantially different labor-capital input ratios are aggregated. This can usually be ascertained from the Census data. Disaggregation will allow a more accurate determination of the effects of trade on factor markets. 
(4) Two or more industries with substantially different ratios of International to domestic prices are aggregated. Efficlent trade may well dictate that the segments with the higher ratios be exports and those with lower ratios be imports.

Country authors w111 find other reasons to disaggregate manufacturing sectors. In general, given the goals of the research, the return from a disaggregation of home goods sectors is not high. Detalled comments on techniques for using Census of Manufacturing data to disaggregate sectors are contained in Project Working Paper No. 2.

\section{ADDITIONAL CONSIDERATIONS}

It has been repeatedly stressed that Individual authors will have to shape their research in light of their knowledge of their country's special circumstances and availability of other studies, as well as data avallability. The iroceding three sections have indicated the main avenues of inquiry that will probably be the focal point for in-depth analyses of the basic findings described in Section III.

There are several possible additional avenues of research that may yield extremely interesting results, although data shortcomings as well as limitations on researchers' own time will probably preclude anything more than brief consideration, or reporting others' research results, in most cases. It seems worthwhile, nonetheless, to mention them briefly, in the hope that researchers will be on the alert for pleces of evidence pertaining to them.

The topics do not have any common theme, so each is discussed in turn below. They are: 1) employment potential of alternative trade strategles 
in primary production; 2) reglonal 1mplications of alternative strategies;

3) the 1mpact of multinationals on employment in alternative lines; and

4) the Impact of uncertainty on 1dentification of comparative advantage and

the related question of the link between static and dynamic comparative advantages. Of these, the first is unquestionably the most 1mportant, but 1t may prove the most intractible.

\section{Primary Production}

In most countries, agriculture is the major primary activity, and attention will focus on 1 t here, as 1 is anticipated that extractive activities will not present special problems, and can be treated in much the same way as manufacturing industries.

There are several important possibilities that should be examined in each country study: 1) It may be that some crops are much more labor Intensive than others and output is affected by the trade regime; 2) if the trade regine has discriminated agalnst export crops, there may be significant employment effects that should be examined both because agricultural output might have expanded more rapidly with attendant employment implications and because export crops might have different employment requirements than food crops for the dorestic market; 3) the trade regime may affect the degree of mechniation in agriculture via protecting or implicitly subsidizing agricultural machinery; and 4) pricing of inputs, especlally fertilizer, can have a significant impact on the comodity composition of agricultural output and consequently on employment.

The difficulties with research on agriculture are likely to be severalfold: 1) It is extremely difficult to get disaggregated data, and those that are avallable are often highly questionable; 2) major questions 
arise with regard to the nature of employment within agriculture, and espectally of the marginal product of labor in small units; 3 ) even when data do exist, they often consist of averages of data from large units and small units. As it is not feasible, and not the intent of this project, to do any original research on the nature of agricultural labor markets, these difficultles w11 often be overwhelming.

Usually, these important questions must be dealt with extremely carefully, and aggregate data obscure more than they reveal. In some cases, euthors may be able to find research already undertaken on the agricultural sector within their country that may enable them to pursue these lines of Inquiry. ${ }^{1}$ In other instances, authors may be able to obtain data with which to disaggregate the agricultural sector in the input-output table, at least to some extent, and to get some estimates of the effects of changing commodity composition of agricultural output on employment. ${ }^{2}$ Additional research, however, will almost Inevitably entall examination of the substitution possibilities of capital for labor, requiring a rellable body of data and

${ }^{1}$ See, for example, Bent Hansen, "Marginal Productivity Wage Theory and Subsistence Wage Theory in Egyptian Agriculture," Journal of Development Studies, July 1966; and also his chapter on Egyptian agriculture in Hansen and Nashashib1, Forelgn Trade Regimes and Economic Development: Egypt, NBER, 1975.

2 There are often significant differences in employment between agricultural activities and, In some countries, those differences may be more important than the differences in employment between manufacturing and agriculture. In those cases, the impact of the trade regime on the composition of agricultural production can be very important. See, for example, A. Berry, "Land Distribution, Income Distribution and the Productive Efficlency of Colombian Agriculture," Food Research Institute Studies, 1973. 
careful econometric estimation.

By and large, it is likely that the promising direction for research will lie in relying upon already-existing studies for estimates of labor market conditions within agriculture and of substitution possibilities vithin that sector. When those estimates are available, it may be possible to simulate the effect of alternative trade regimes on employment by taking the estimated elasticity of substitution of capital for labor, and applying it to the estimated shadow price of imported capital goods relative to the shadow price of labor. Such a procedure would be rough and ready, but would also offer one means of obtaining some insights on the impact of the trade regime on factor proportions without requiring special studies. Authors can then concentrate their own research efforts on disaggregation of agricultural data for use in the optimization models, and on lines of inquiry suggested in Sections IV and $V$.

$\underline{\text { Regional Implications }}$

In addition to concern with employment aggregates, most developing countries have become increasingly aware of the problems associated with the concentration of population and employment in their already overcrowded cities. An important question is whether there are different locational Implications of export and import-substitution strategies, aside from any differences in the agriculture-industry emphasis of the two strategies.

Hypotheses abound, although none have any very solid analytical underpinning. One could, for example, conjecture that labor-intensive industries, in which developing countries have a comparative advantage, must in any event be relatively location-untied, simply in order to be viable export activities. If that were so, it might then follow that there would be 
relatively more latitude as to choice of location of those industries within countries, contrasted with import-substitution industries. There are several weaknesses in the hypothesis: being relatively non-tied to a location does not imply that transport costs do not matter, especially in countrles where inland transport costs are already very high, either at market or at shadow prices; an Industry could require a city of large size simply in order to attract the labor force, subcontractors, and other needed inputs, without belng tied to a specific location; and so on.

Not only are alternative hypotheses relatively weakly based analytically, but it is doubtful whether data avallabllity and authors' judgments as to the payoffs from pursulng varlous lines of research will permit any systematic examination of the implications of alternative strategles for the location of employment. Nonetheless, authors might be on the alert for any pleces of evidence that do suggest any significant differences (or the absence of any differences) In the locational implications of the two strategles.

\section{Multinational Corporations}

Robert Lipsey of the NBER staff in New York will attempt to use a spectal run of data avallable at the Bureau with a view to investigating the degree to which multinational corporations alter their factor proportions In response to changes in factor prices. Results of that study w111 become avallable to country authors as the research progresses, for whatever light they shed on conditions within individual countries.

In addition to the light that multinational corporations' behavior can possibly shed on substitution possibilities, a number of other questions have been raised in the 11terature, and it may be the case that in some countrles, authors fudge those questions to be sufficlently important to 
warrant further investigation. In tnost instances, it will probably be desirable to rely on existing studies, and to interpret data, rather than to attempt fresh data analysis.

First, there is the frequently-heard assertion that multinationals often invest in particular countries in ways that preclude exports from their affiliate firms. In some instances, the $\mathbb{N N C}^{\prime} s$ undertake the investment in import-substitution industries only in response to increases in protection. In those cases there does not seem to be any legitimate question, as the commodity would not in any event be exported. In other cases, however, it may be that the optimizing model described in Section VI, or other pieces of evidence, suggest that MNC's have invested in industries that would otherwise have been export industries and thus have influenced the commodity composition of trade. Where this hypothesis seems important, authors may wish to pursue it, although care should be taken to be sure that their lines of research will yield results: unless reasonable tests of hypotheses can be formulated, in such a manner that research will yield results, it will not necessarily pay to allocate a great deal of effort to the question. ${ }^{1}$

Secondly, there is the question as to whether multinationals adopt the technology of the parent company, presumably capital-intensive, when another technology, that might employ more labor, is available. In some

${ }^{1}$ A basic problem is why a multinational corporation would prevent exports if the country had a natural comparative advantage and was a lowcost producer of the commodity in question. Of equal importance is the consideration that other firms would be able profitably to produce the comodity. 
instances, studies may exist comparing the behavior of multinational and domestic firms, 1 and their results may prove useful. Lipsey's research may also throw light on this question. Authors may wish to undertake some research in this direction themselves, if in their fudgment, multinational firm behavior is a sufficiently important part of the explanation of the trade strategy-employment relationsh1p.

The Impact of Uncertainty and Dynamic Comparat Ive Advantage

As is the case in most empirical research, there are some important considerations that are difficult to handle. For analysis of the tradeemployment relationship, two such questions are the impact of uncertainty upon the optimal composition of trade, and the relationship of dynamic to static comparative advantage.

Obviously, the "optimal" production pattern would differ in a world of uncertainty from that which would occur if all future prices were known. Iittle can be done with regard to that consideration, except to use past history as something of a guide. In particular, it may prove desirable to take means and variance of prices of major traded commodities, in estimating ERPs and related varlables, rather than using observations from a single time period. Of course, it may not prove possible to do this for all commodities, but such a procedure will be warranted when price fluctuations are belleved to have been large. Beyond taking means of price varlables, however, little can be done about uncertainty inherent in changing world market conditions.

${ }^{1}$ See Benjamin Cohen, "Comparative Behavior of Foreign and Domestic Export Firms in a Developing Economy," Review of Economics and Statistics, May 1973. 
The question of optimal dynamic comparative advantage is equally important and even more intractable. There is a question as to the extent to which countries should now produce commodities in which they will have a future comparative advantage: as seen in "Growth, Distortions, and Patterns of Trade Among Many Countries, "i one would normally expect comparative advantage to shift over time, but that in itself does not indicate that commodities should be produced today simply because they will be exported tomorrow. It is also important to note that comparative advantage generally would be expected to shift smoothly if the factor proportions model is correct: one would not forecast that highly capital-intensive commodities would enter Into a country's optimal production structure until production of less capital-intensive commodities not currently produced had been inaugurated. Country authors should bear these considerations in mind in evaluating the trade-employment relationship for their countries, and should communicate any suggestions for ways of dealing with these issues to other project participants. By and large, however, considerations of uncertainty and dynamic comparative advantage are factors that will have to be borne in mind when interpreting the results of the research, and are not themselves Iikely to call for additional empirical data.

\section{Additional Topics}

In any research project of this nature, there are bound to be additional hypotheses that emerge in the course of the research. Individual researchers are requested to be on the alert for such hypotheses, and to communicate them to other country study authors when they arise. In the Bhagwat $1-k r u e g e r$ project, interaction of this kind was one of the very fruitful outcomes of the project, and it was frequently the case that a pattern, 
not initially mentioned, was thought to be unique to one country, but, when discussed, tumed out to be common to several of them. For this reason, it is hoped that, by the time of the next working party of country authors, authors will have given thought to the way in which the lines of research suggested here are appropriate or inappropriate for their countries, and also to additional avenues of endeavor. 
APPENDIX. UNIFORIY TAELE NUMBERING SCHELES FOR COUNTRY STUDIES

One of the major problens with the results of the Bhagwati-Krueger project has been that attempting to locate the same data for several countries has proved extremely difficult and involved a search through all the text tables. Our studies will prove more useful to all (including each other) if we adopt a common numbering system for data tables. This will enable country authors to contrast their data with similar data for other countries, without long searches through manuscripts.

It will be recalled that, at the first working party, a suggested covering format was suggested for each distribution of material from country authors. It seems simple enough to expand that format to include data tables, so that country authors can distribute materials, labelled by Table Number, as data become available, and the appendix tables can be a standard part of each cover format.

I propose that the numbering system presented below be used for each country study. For example, an input-output flow table will carry the number IA for each country study; a table covering trade with developing countries will be IIIC in all cases, and so on. ${ }^{1}$ obviously, not all country studies will contain all data, but that fact can be noted on the cover sheet accompanying distributions, and thereby save long searches for non-existent data.

In addition to the six categories with which basic data can be numbered,

Fote that an "X" category under each number has been reserved for a statement as to the ways in which data were "massaged" in order to meet the needs of this project. 
it will prove extremely useful to have a master table by comodities, showing the key 1tems, and the way in which aggregates were derived. The table categorles listed below can be a standard, and presented in an Appendix I in each country study. The master table, which is described afterward, can then become Appendix II of each study.

\section{Contents of Appendix I in Country Studies}

The precise content of each table will naturally vary with data avallabllity, so all that is proposed here is a numbering sequence. Suggestions for extensions and/or modifications of this scheme are welcome. The table numbering system proposed is as follows:

I. INPUT-OUTPUT DATA [If data are available for more than one year, the table sequence is repeated for each year. For example, if data are available for both 1970 and 1971, the corresponding flow tables are designated IA1970 and IA 1971].

A. FLOW TABLE(S). (These are the basic I-0 tables which contain the adjusted interindustry flows for a particular base year.)

B. DIRECT REQUIREMENTS. (These are the $a_{\text {if }}$ coefficients that correspond
to Tables(s) IA.)

C. DIRECT AND INDIRECT REQUIREIEINTS. (These may represent a full $(I-A)^{-1}$, or may be limited to a calculation of indirect requirements for home goods. Tables(s) IC are computed from data in Table(s) IB and do not represent new data.)

D, E, F, etc... SUPPLEMENTARY I-0 INFORMATION. (These tables will vary from country to country depending upon individual circumstances.)

K. SECTORAL CLASSIFICATION. (Each $\mathrm{I}-0$ sector is here described in terms of its SITC equivalents. Also, each sector is designated as resourcebased tradable, other tradable, or home good as described in PWP1.)

X. RECTIFICATION AND ADJUSTMENT PROCEDURES. (The ways in which primary data were adjusted to meet the requirements in the present analysis are described in this table.)

II. SUPPLEMENTARY PRODUCTION AND VALUE ADDED DATA. [Sectoral data beyond those given in the I-O tables are presented in these tables. Some of these data are derived from primary sources such as Manufacturing Censuses. Other data, such as intermational value added, are constructed from data given in other tables.] 
A. DOMESTIC VALUE ADDED BY SECTOR.

B. INTERNATIONAL VALUE ADDED BT SECTOR.

$C, D, E$. OTHER PRODUCTION DATA. (These tables might include such things as output levels by firm size or geographic region. Correspondingly, breakdowns may be given in the labor data described below.)

K. SECTORAL CLASSIFICATION. (Necessary only insofar as it differs from classification given in Table IK.)

X. RECTIFICATION AND ADJUSTMENT PROCEDURES 。

III. TRADE DATA. [These tables give actual international trade flows for year $(s)$ and sector classification(s) which correspond to the I-0 data.]

A. TOTAL TRADE FLOWS.

B. TRADE FLOWS WITH DEVELOPED COUNTRIES.

C. TRADE FLOWS WITH DEVELOPING COUNTRIES.

D, E, F. OTHER APPROPRIATE TRADE BREAKDOWNS.

K. SECTORAL CLASSIFICATION. (The trade data may have a more detailed breakdown than the $I \rightarrow 0$ data.)

X. RECTIFICATION AND ADJUSTMENT PROCEDURES.

IV. INTERNATIONAL PRICES, TARIFF RATES AND EFFECTIVE PROTECTION RATES.

A. INTERNATIONAL PRICES BY SECTOR. (These are international prices that correspond to the unit domestic prices used for the I-O data.)

B. TARIFF RATES BY SECTOR.

C. EFFECTIVE PROTECTION RATES BY SECTOR.

D, E, F. OTHER DATA.

K. SECTORAL CLASSIFICATION. (It is possible a sector may have several different prices for its various components.)

$X$. RECTIFICATION AND ADJUSTMENT PROCEDURES. (Descriptions of how international prices were computed are given here.)

V. LABOR DATA. [Under ideal conditions, each of the following tables will have a part 1 which gives labor force and/or employment data, and a part 2 which gives corresponding wage and salary information.]

A. LABOR FORCE (OR EMPLOYMENT) BY SKILL, EDUCATION, AGE, SEX AND SECTOR. (It is unlikely that sector data can be broken down by all four factors in any one country. Table VA will contain a feasible breakdown for each country.) 
B. PRINCIPAI LABOR DICHOTOMIES BY SECTOR. (Possible breakdowns include production vs. nonproduction workers, daily vs. salary workers, large firms vs. small.) (It is important to have at least one major dichotomy by sector with corresponding wage and salary data.)

C, D, E. OTHER LABOR ATTRIBUTES.

R. ATTRIBUTE CLASSIFICATIONS. (This table contains descriptions of the special breakdowns used in Tables VA through VE.)

X. RECTIFICATION AND ADJUSTMENT PROCEDURES.

VI. CAPITAL AND FACTOR PROPORTIONS DATA.

A. CAPITAL STOCKS BY SECTOR.

B. CAPACITY UTILIZATION RATES BY SECTOR.

C. COST OF CAPITAL SERVICES BY SECTOR.

D, E. OTHER CAPITAL DATA.

F. CAPITAL-IABOR RATIOS BY SECTOR. (These critical ratios are constructed from the labor data in Tables $V$ and capital data given here.)

X. RECTIFICATION AND ADJUSTMENT PROCEDURES.

Contents of Appendix II.

To get the aggregate employment per unit estimates outlined in Table 1, there will be a lot of data used. It may be of great interest for the synthesis of results, and for purposes of later research, to learn about the comparability of sectors across countries.

To that end, it seems desirable that there be a table which brings together the data, and the means used for aggregation. The seventeen column headings would be:

1. Type of good (1.e., natural-resource based tradable, HoS tradable, home good).

2. Percent of 2-digit total covered by this SIC category.

3. Intermational value of exports.

4. International value of imports.

5. Value of domestic production.

6. Value of domestic consumption.

7. Effective protection rate. 
8. Specialization index.

9. Domestic value added.

10. International value added.

11. Direct labor per unit of value added.

12. Indirect labor (in home goods) per unit of value added.

13. Direct and indirect labor per unft of output (sum of 11 and 12).

14. Direct capital per unit of output.

15. Indirect capital (in home goods) per unit of output.

16. Direct and indirect capital per unit of output (sum of 14 and 15).

17. Capital labor ratio (16 divided by 14 ).

An example of what this might look like is provided below. The numbers are hypothetical, but illustrate the sorts of aggregation involved. It should be noted that the first two rows represent the totals for the exportables and import-competing commodities in a hypothetical two-digit textile sector. In the example given, all data are available for subsectors so that the totals are simply derived from the data given below them. However, it may be in many instances that some items are available only at the sectoral level, while others are avallable for subsectors. For example, it may be that authors have to use the same ratio of domestic value added to domestic value of output for each subcategory in an industry but can derive separate labor and capital coefficients for that value added. Phenomena like that can be noted in the tables, thereby indicating the extent to which data for subsectors are independent observations.

Authors may wish to examine the means used for aggregation in the hypothetical data in the master table, and suggestions are welcome. However, regardless of which means is used, there are bound to be instances when an alternative method is preferable. In such cases, the Notes to the table can Indicate the ways in which techniques of aggregation differ from those in the standard table we agree upon. 


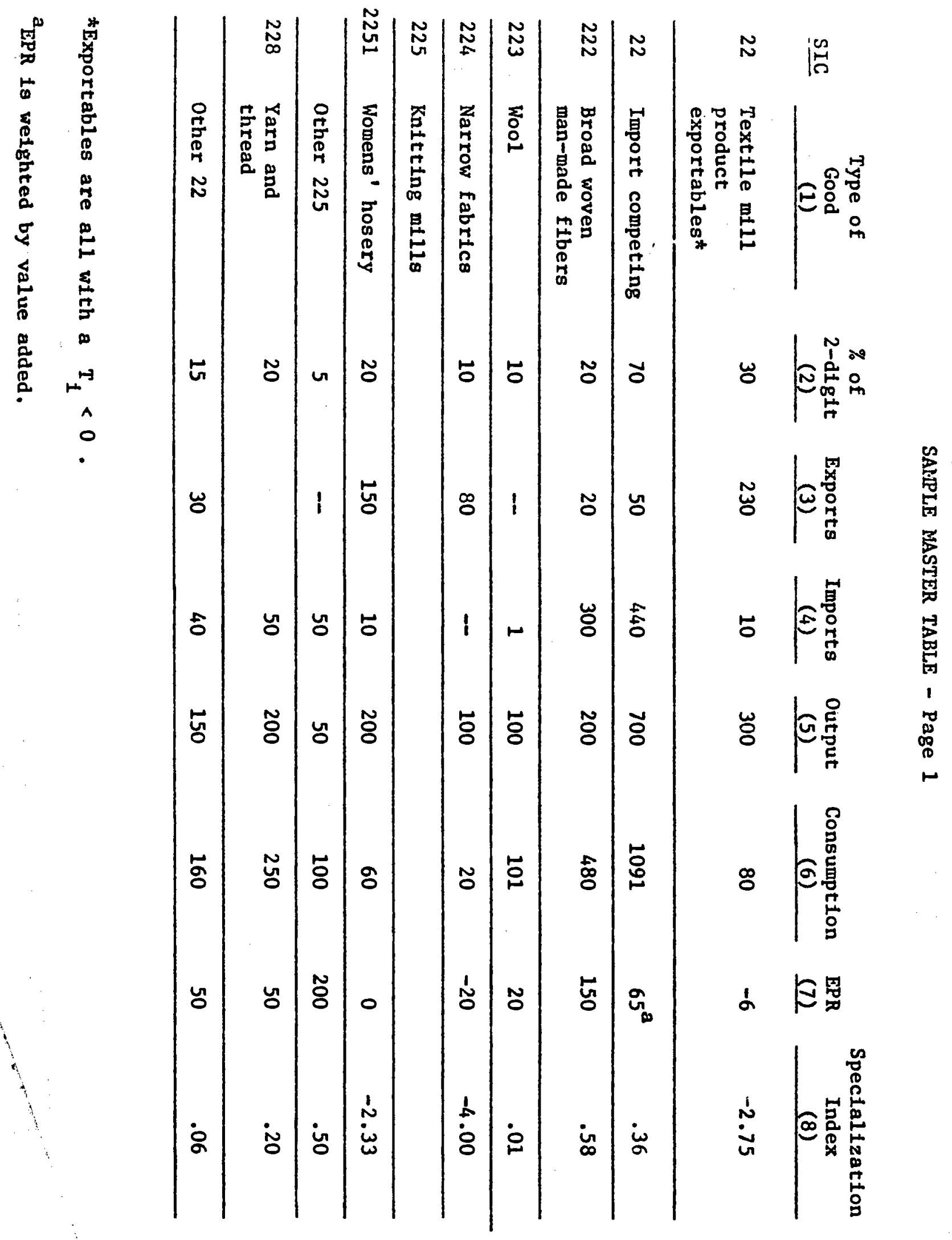




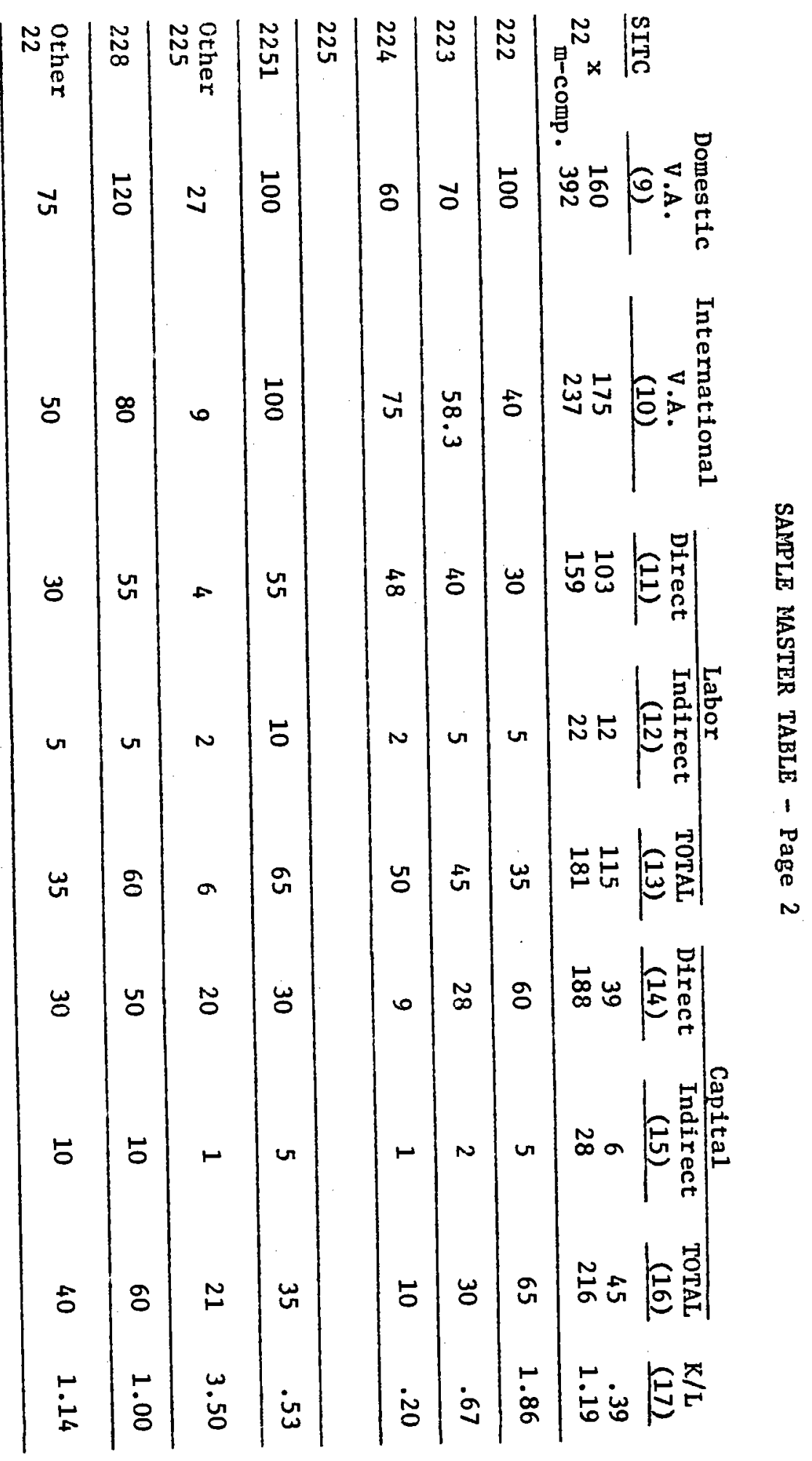

